\author{
Оксана Чепелик \\ кандидат архітектури \\ провідний науковий співробітник \\ Інститут проблем сучасного мистецтва \\ НАМ України \\ oksana.chepelyk@gmail.com

\section{Oksana Chepelyk} \\ $\mathrm{PhD}$ in Architecture \\ leading researcher \\ Modern Art Research Institute \\ of the National Academy of Arts of Ukraine \\ orcid.org/0000-0002-2836-8611
}

\title{
АРТ + ФЕМІНІЗМ 2020: УКРАЇНСЬКИЙ І СВІТОВИЙ КОНТЕКСТИ
}

\author{
Art + Feminism 2020: Ukrainian And WorldWide Contexts
}

\begin{abstract}
Анотація. Розглянуто мистецький доробок міжнародних мисткинь, таких як Мір'яна Батініч, Оксана Чепелик, Деббі Каруана Дінглі, Тереза Дебоно, Емма Фсадні, Анна Гріма, Глорія Оярзабал, Енріке Табоне, Жана Бусуттіли Залеські, представлений на виставці «Арт + фемінізм 2020», яка проходила 7 лютого — 23 серпня 2020 року в Арт Центрі Креативний простір на Мальті, присвячений феміністичній проблематиці, для залучення його до національного культурологічного дискурсу як привід до роздумів і дискусій.

Опрацьовано теми, які розробляють мисткині, як то розширення прав і можливостей молодих дівчат і жінок для поєднання професійної реалізації і материнства, біоетика і права жінок в умовах комерціалізації репродуктивних технологій, конфлікт між традиційними гендерними нормами і упередженнями та сучасними очікуванннями, непроговорені історії в патріархальному суспільстві, історична інфантилізація жінки шляхом колонізації свідомості, історія мистецтв в епоху матріархату з фокусом на жіночій перспективі із забезпеченням візії доісторичних артефактів сучасною рамкою і використанням новітніх технологій. Відзначено широкий спектр художніх практик, якими займаються мисткині, - від традиційного живопису, графіки та скульптури до таких, що пов'язані з використанням медіа: фотографії, відео та керованих даними медіаінсталяцій.

Наголошено на важливості культурологічних рефлексій гендерної проблематики і вбудовування українського сучасного мистецтва в глобальні явища для розвитку теорії і практики та важливості залучення українських проектів, продемонстрованих за кордоном до українського мистецького дискурсу. Відзначено плідність зусиль щодо зменшення гендерного розриву у Вікіпедії задля висвітлення роботи жінок-художниць та їх внеску у мистецтво.

Визначено місце сучасного феміністичного мистецького доробку - як культурного і політичного явища в суспільному житті, що працює на становлення нових цінностей та нової свідомості і може слугувати інструментом для культурної політики України.

Ключові слова: мистецтво, фемінізм, гендер, рівність, репродуктивна технологія, колонізація свідомості.
\end{abstract}

Постановка проблеми. Поза тим, що історія українського мистецтва XX століття мала страшні втручання та суттєві замовчування, писалася на догоду домінуючому колоніальному, тоталітарному і гендерному дискурсу, а українське сучасне мистецтво за відсутності музеїфікації упродовж 30 останніх років і взагалі є територією випаленої землі в боротьбі за ресурс, в українському культурологічному дискурсі підважуються ідеї фемінізму, чи гендеру у мистецтві з позиції сьогоднішнього дня, порадами ліпше облишити гендер у мистецтві і говорити про теми й ідеї, а не про статеву приналежність авторів. Гендерна проблематика на теренах України викликає запеклі дискусії, що ставлять під сумнів доцільність їі розробки в XXI столітті, а фемінізм слугує «червоною ганчіркою» для його противників не як теорія, що бореться за рівні права, а як така, що підкреслює і поглиблює відмінність між чоловіками і жінками. Але відмінність - це поняття, що відкриває шлях до дослідження та до розуміння відмінності як позитивної умови екзистенції, як можливості, що відкриває свіжий погляд на Іншого і передбачає необхідність діалогу. Ці дискусії, що виникають сьогодні, свідчать про відсутність розуміння або здатність не помічати гендерних утисків, тобто свідомо уникати орієнтації на відновлення рівноваги в суспільстві і мистецтві. Нагальною є необхідність розглянути феміністичну проблематику та визначити, як сповідувати практики рівності як в житті, так і в мистецтві, як зменшити гендерний розрив у Вікіпедії задля висвітлення роботи українських художниць та їх внеску у мистецтво.

Зв'язок із важливими науковими та практичними завданнями. Тема статті пов'язана з загальнодержавною програмою Інституту проблем сучасного мистецтва Національної Академії мистецтв України, зокрема з темою «Українське мистецтво на зламі XX-XXI століть і міжнародний контекст». 
Зв'язок авторського доробку із важливими науковими та практичними завданнями. Гендерна проблематика розроблялася мною в мистецтві і кінематографі з кінця 90-х, можна згадати перформенси «Народження Венери» (1995), «Мандрівний острів Лесбос» (1996), «Одяг-сховок?» (1996), відео-проект «Очевидна невідворотність» (1998), фільми «Улюблені іграшки лідерів» (1998) [1], «Хроніки від Фортінбраса» (35 мм, 2001) (іл. 1), «У затишку білих акацій» (2013), повнометражний цикл «Жінка і війна» (2014) (іл. 2), що демонструвався на Міжнародному кінофестивалі Сinemadamare в Італії, а в програмі Final Cut в рамках 71-го Міжнародного кінофестивалю у Венеції був показаний короткометражний фільм «Віч-на-віч» 3 цього циклу. Проект «Очевидна невідворотність", побудований на сповіді, створений за 20 років до відомого флешмобу «Я не боюсь сказати» та «Me too», демонструвався 1 березня - 6 травня 2018 року в рамках виставки «Flashback. Українське медіа-мистецтво 90-х» в Мистецькому Арсеналі як двоекранна відеоінсталяція з циклом фотографій. I, власне, ці проекти та фільми працювали $з$ темами, які були визначені як основні в рамках виставки «Арт + фемінізм 2020» на Мальті.

Аналіз останніх досліджень і публікацій. Останньою вагомою публікацією, що стосується внеску українських художниць в розвиток мистецтва, стала книга «Чому в українському мистецтві є великі художниці» (упорядниця Катерина Яковленко) 2019 року, результат мистецтвознавчої праці колективу "Дослідницької платформи", започаткованої в ПінчукАртЦентрі. Учасницям цього проекту довелося розкопувати інформацію, висвітлювати і систематизувати процеси і явища, що відбувалися з 1980-х років, і які не віднайшли свого місця ні в мистецтвознавчому, ні в культурологічному, ані у феміністичному дискурсі, адже кожен з них страждав своїми колоніальними хибами - був мало розвинений i, здебільшого, орієнтований на московську метрополію.

3 появою книжки «Чому в українському мистецтві є великі художниці» українські мистецтвознавчі студії вийшли на новий рівень, багато українських мисткинь віднайшли своє місце в українському культурологічному дикурсі. Залучаючи до свого аналізу розфрагментовані дискурси різних зацікавлених груп, що оберталися навколо певних кураторських ініціатив, авторки спробували вибудувати певну тяглість жіночої лінії в українському мистецтві XX-XXI століть, заповнюючи лакуни і залучаючи обійдені чи забуті факти.

Так само, як щодо багатьох мисткинь всередині країни довелося провадити польові дослідження, щодо різних закордонних виставок, проектів, презентацій та залучень, українські студії й досі страждають відсутністю таких пошуків, тому аби не довелося вести розкопки в майбутньому і щодо українського сліду в проекті «Арт + фемінізм 2020» в Spazju Kreattiv на Мальті (іл. 3), маю на меті синхронізувати у часі демонстрацію і аналіз та рефлексію щодо робіт, представлених в рамках проекту, аби залучити до українського культурологічного дискурсу і не множити лакуни і зони замовчування.

Цілі статті. Метою статті є розгляд міжнародного мистецького доробку, представленого на виставці "Арт + фемінізм 2020", яка проходила 7 лютого - 23 серпня 2020 року в Арт Центрі Креативний простір, що розташований в історичному Бастіоні святого Якова (іл. 4), в столиці Мальти Валлетта, з різними культурними програмами, як привід до роздумів і дискусій, рефлексій щодо українського і світового контекстів для залучення ïх до національного культурологічного дискурсу.

Викладення основного матеріалу дослідження. "Art + Feminism" - це щорічний всесвітній проект, що проходить з 2018 року 3 метою додати матеріали до Вікіпедії про жінок-художниць. Вже втретє на Мальті відбувається захід, що пропонує серію кураторських виставок у трьох локаціях, де представлені нові роботи як відомих, так і молодих художниць. Ця ініціатива стала можливою завдяки постійній співпраці між Мальтійською Вікімедією, Фондом МЗР та Spazju Kreattiv / Креативним простором. Іншими представниками співпраці є Незакінчений арт-простір та Фонд Габріеля Каруана.

В рамках виставок відбулася низка семінарів з редагування та правок Вікіпедії. Ці заходи і надалі стосуватимуться зменшення гендерного розриву у Вікіпедії задля висвітлення роботи жінок-художниць та їх внеску у мистецьку сцену на Мальті. Після двох попередніх видань "Арт + Фемінізм» / «Art + Feminism» на Мальті в Арт Центрі Креативний простір / Spazju Kreattiv запросив невелику кількість жінок-художниць, чиї роботи є частиною художньої колекції Fondazzjoni Kreattività, аби представити їхні нові роботи поряд з іншими міжнародними художницями, які відгукнулися на відповідний заклик. Виставка представила твори восьми міжнародних та мальтійських художниць, коло художниць охоплює три покоління - від усталених імен до нових талантів: Мір'яна Батініч, Оксана Чепелик, Деббі Каруана Дінглі, Тереза Дебоно, Емма Фсадні, Анна Гріма, Глорія Оярзабал, Енріке Табоне та ретроспективу мальтійско-американської мисткині Жани Бусуттіли Залеські. Роботи демонструють широкий спектр підходів до теми виставки, залучаючи різноманітні засоби, медіа та презентаційні методи мисткинь-учасниць виставки.

Тоні Сант, креативний директор Spazju Kreattiv, виступив куратором міжнародного проекту "Арт + Фемінізм» / "Art+Feminism». Виставка досліджує питання, що таке жінка в 2020 році, розглядаючи тему колонізації свідомості й спотворення ідентичності та інші проблеми крізь феміністичний об’єктив. Вона 


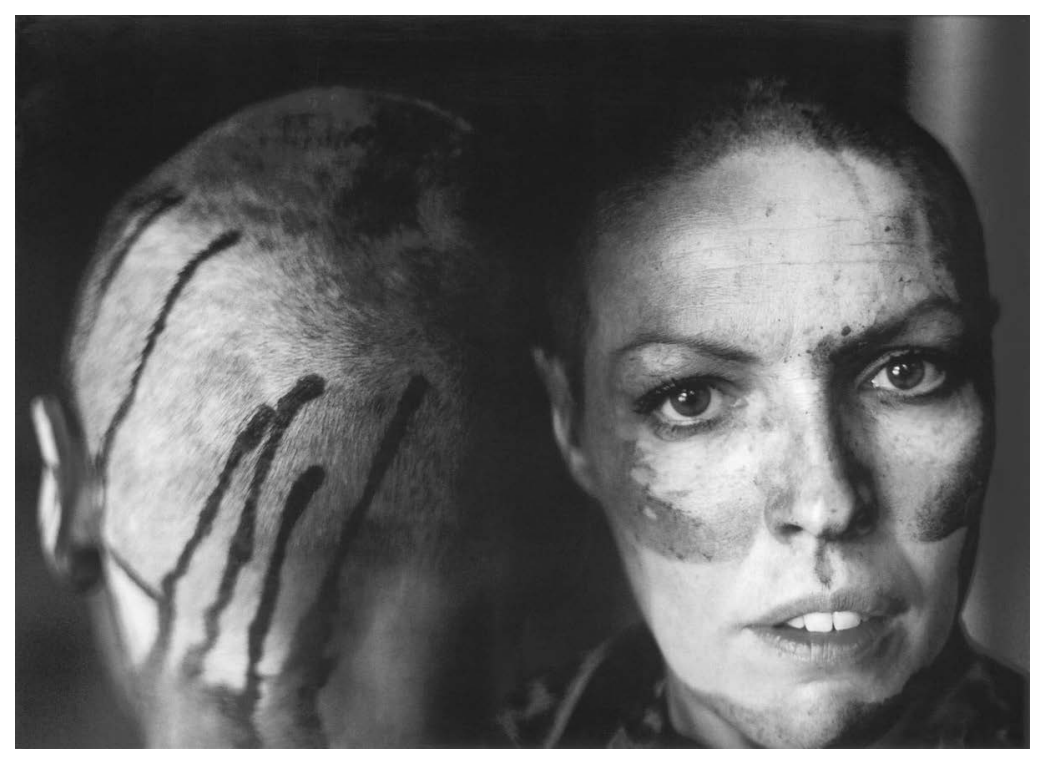

1. Оксана Чепелик «Хроніки від Фортінбраса», 35 мм, 2001

забезпечила можливість розглянути художні погляди та замислитись над минулими та сучасними образами феміністичного дискурсу. Відносини між матір'ю та дитиною - це тема, з якою працювали митці, яку оспівували протягом історії, така, що має глибоке інтимне переживання. Куратор подає широкий спектр феміністичного прочитання цієї теми в роботах мисткинь, що відрізняється від замилування і умиротворення.

Хорватська художниця Мір'яна Батініч взяла участь у виставці «Арт + Фемінізм 2020» 3 роботою під назвою «Рідке золото» (іл. 5). Мисткиня подала заявку на конкурс, адже роботи, що стосуються фемінізму, є дуже актуальними і в XXI столітті. Мір'яна Батініч опинилася в іншій країні, а також в новій для неї ролі матері, тому вона опрацьовує виклики, що висвітлюються фемінізмом через материнство. 3 цією роботою мисткиня звернулася до двох найбільш важливих проблем сучасного феміністичного дискурсу - втрати ідентичності та індивідуальності. Ці проблеми Мір'яна Батініч розглядає у своїй роботі «Рідке золото» через власну історію материнства і особистий досвід близькості - тепер як мати по відношенню до людини, до якої вона ставиться як до «свого найкращого мистецького твору» - своєї дитини на ім'я Міша. На трьох рулонах паперу, розкатаних на висоту стіни до підлоги, з'явився один гігантський чорнобілий рисунок олівцем, що живо нагадує образ П'єти, але $з$ дочкою на руках (іл. 6). Поза сакральними алюзіями Художниця також надсилає меседж щодо розширення прав і можливостей молодих дівчат і жінок. Адже, якщо роззирнутися довкола, то все ще не настільки звично бачити, щоб успішні жінкинауковці або художниці були б матерями. $€$ все ті ж самі соціально-психологічні та фінансові навантаження, з якими жінкам доводиться мати справу, коли вони намагаються робити як мінімум дві важливі речі одночас- но: займатися дитиною та серйозною інтелетуальною працею. Так, в протоколі методичного комітету відомої Маастріхтської Академії імені Яна ван Ейка від жовтня 2007 року зазначалося, що й досі не існує ніяких правил стосовно художниць, що завагітніли в період роботи над проектом, з відповідним висновком необхідності встановлення таких правил.

Авторський проект «Генезис», що стосується теми народження, був відібраний для участі у виставці «Арт + фемінізм 2020» в результаті міжнародного конкурсу і задля його експонування був сконструйований спеціальний простір з віковим обмеженням +18. За висловом куратора виставки: «Оксана Чепелик - учасниця з України, одна з міжнародних художниць, яка представлена в проекті “Art + Feminism 2020". Iї творчість і проект “Genesis” стосується сучасних питань, пов'язаних із жіночим тілом та народженням. Аудіовізуальний проект об'єднав моніторинг народжуваності в різних країнах світу та роботу з тілесністю" [2]. Проект говорить про ціннісність людини за "нових форм материнства", завдяки яким жіноче тіло в умовах сурогатного материнства стає контейнером для розведення людського матеріалу та про небезпеку для життя без найважливішого - любові матері та дитини, без якої світ міг би повністю втратити своє відчуття та сенс існування. Підтвердження цьому не забарилося, коли за умов легальних практик сурогатного материнства в Україні новонароджені під час пандемії немовлята опинилися заблокованими в «зоні очікування» за умов закритих кордонів. Мультимедійний проект «Генезис», пов’язаний 3 новітніми технологіями, закладає коди, якими він послуговується у світлі актуальних світових тенденцій і сучасних реалій.

«Генезис», розвиваючи стрижневу ідею генофонду, стосується теми народження, структурований як ДНК з подвійною спіраллю і основами, розташованими горизонтально 


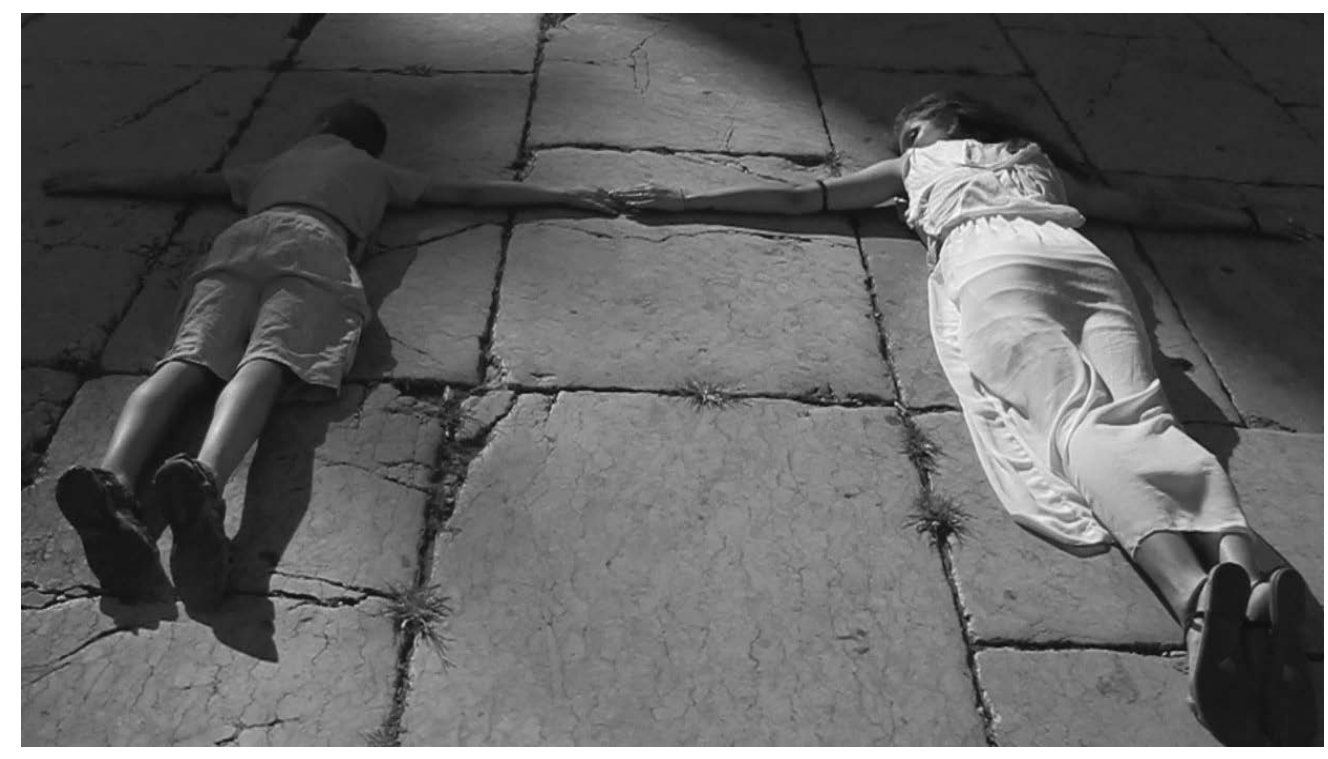

2. Оксана Чепелик «Жертвопринесення» із циклу «Жінка і війна», відео, 2014

між двома спіральними ланцюжками, що об’єднують гендерну проблематику, часо-простір, інформаційні потоки, новітні технології, scienceart, естетику взаємодії, процеси мережування, репродуктивні технології, комерціалізацію і фемінізм. Ці одиниці як «гени містять відкриту рамку зчитування, яку можна транскрибувати, а також регуляторні послідовності, такі як промотори та підсилювачі, які керують транскрипцією відкритої рамки зчитування» [3, с. 824] соціальної сфери.

«Генезис» - це довготерміновий проект, робота над яким розпочалася ще 2004 року. Ідея виникла внаслідок дуже особистого стану, що співвідносився в часі і просторі 3 суттєвими змінами політичної матриці. Очікування дитини спонукало до реалізації фотота відеозйомки, що розглядає жіноче тіло в багатовимірному мікро-макропрочитанні. Відео демонструє сучасний орнамент, створений з тату і мізансцен, які розігруються на тілі вагітної жінки, що є відсилкою до цивілізаційних та екзистенційних катастроф. Адже мініатюрні фігурки людей, що завмерли на поверхні сфери живота матері, формують образ цивілізаційного поля планети Земля. Їх довга вервечка витягнулася в очікуванні над тату із зображенням плоду, як над кратером вулкану, де народження подається як Великий Вибух по своїй візуальній гостроті. Проект це дослідження системи генезису, сконцентроване на символічному акті народження. Він об’єднав простір чотирьохекранної відеоінсталяції та інсталяцію «Початок / Origin». На чотирьох екранах можна побачити: а) відео «Пульс_Життя" / «Pulse_Life», що демонструє ехокардіограму серця матері та дитини - серцевий пульс є символом ритму життя, а серце - нашим внутрішнім годинником та генератором; в організмі вагітної жінки співіснують два різні пульси, де серце плоду вибиває 120-140 ударів, та «УЗД / USE» із зображенням ультразвукового дослідження плоду; б) відео «Female ID»; в) відео «Народження / Birth» 3 макропланом всього процесу народження дитини від початку пологів і до народження плаценти, найдорожчого комерційного матеріалу, що експортується на захід для виготовлення косметики та шампунів; г) Відео, що $є$ документацією інсталяції «Початок / Origin», реалізованої в чотирьох містах, що працює як моніторинг народжуваності в реальному часі. B data-driven інсталяції кожне нове народження викликає візуальні зміни в проекції з відеозображенням немовляти, що відбувається приблизно через кожні дві хвилини у Нью-Йорку, через 20 хвилин у Санта-Фе у штаті Нью-Мексико (США), в середньому кожні 1,5 хвилини - при кожному наступному народженні в Україні та через кожну хвилину у Каліфорнії. Таким чином, інтервенція «Початок / Origin" дозволяє створювати унікальні інсталяції для різних регіонів світу, де він експонується. Надувна метрова повітряна куля, піднята над боксом в просторі Spazju Kreattiv, аби слугувати сферичним екраном для відеопроекції, працює як моніторинг народжуваності на Мальті, відбиваючи орієнтовно кожну годину нове народження (iл. 7). Форма кулі для інсталяції «Початок / Origin» була обрана не випадково - бінарність мікромакроопозиції виявляється сутнісною, коли відеопроекція на повітряну кулю, що демонструє зображення немовляти в променях ультразвукового дослідження, трансформує Біологічну клітину в Планету Людей.

У відеоінсталяції задіяний препарований звук ДНК (американські вчені записали ії мелодію, і я мала можливість співпрацювати 3 ними в університеті Лос-Анжелеса - UCLA в рамках дослідницької програми Фулбрайту 2003-2004 років), а кожне наступне народження відбивається потужним аудіосплеском, одержаним під час проведення ультразвукового дослідження артерії людини. Тобто у кожному випадку йдеться про аудіорепре- 


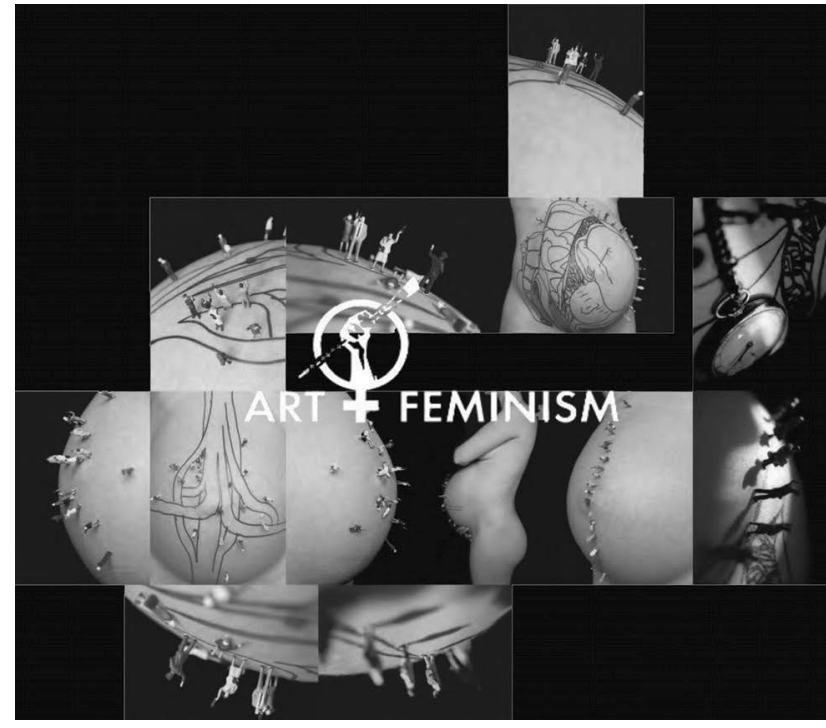

3. Оксана Чепелик «Генезис», афіша виставки «Арт + фемінізм 2020», Валлетта, Мальта

зентацію життя, пов'язану з новітніми технологіями.

Відео «Female ID» звертається до глобальної проблеми сурогатного материнства, яка у всьому світі є темою палких дискусій (іл. 8). Сурогатне материнство - «репродуктивна технологія, при якій жінка добровільно погоджується завагітніти з метою виносити і народити дитину яку потім віддадуть на виховання іншим особам, які і будуть юридично вважатися батьками даної дитини» [4, с. 5]. 3астосування цих методів репродукції, пов'язане з багатьма проблемами етичного, медичного і юридичного характеру, поставило людство перед дилемою - вирішити проблему безпліддя, а чи йти шляхом комерціалізації, яка є засобом експлуатації жінок в ролі платних інкубаторів, про заборону яких мовиться в Брюссельській декларації Всесвітньої медичної асоціації (1985). Сурогатне материнство заборонене законом в Австрії, Норвегії, Швеції, Франції, деяких штатах Америки, Італії, Швейцарії і Німеччини (в Німеччині заборонена допомога бездітним парам, зважаючи на її «аморальність»). Комерційне сурогатне материнство зазвичай визначається в емоційно навантажених і потенційно образливих термінах, таких як "матки для оренди» або «ферми немовлят», та оперують такими поняттями, як ринок, оренда тіла, оплата послуг, виторг, сировина. На комерційній основі дозволено в більшості штатів Америки, Південно-Африканській республіці, Індії, Росії, Грузії та Україні. Як ставитися до того, що «замовлене немовля», пов'язане з сурогатною мамою не тільки пуповиною протягом дев'яти місяців, але і глибокими емоційними зв’зками, які потім, коли дитину потрібно передати новим батькам, розриваються найжорстокішим і найхворобливішим чином? Проект ставить гоголівське запитання в термінах XXI століття, чи «Живі гроші - мертві душі»?

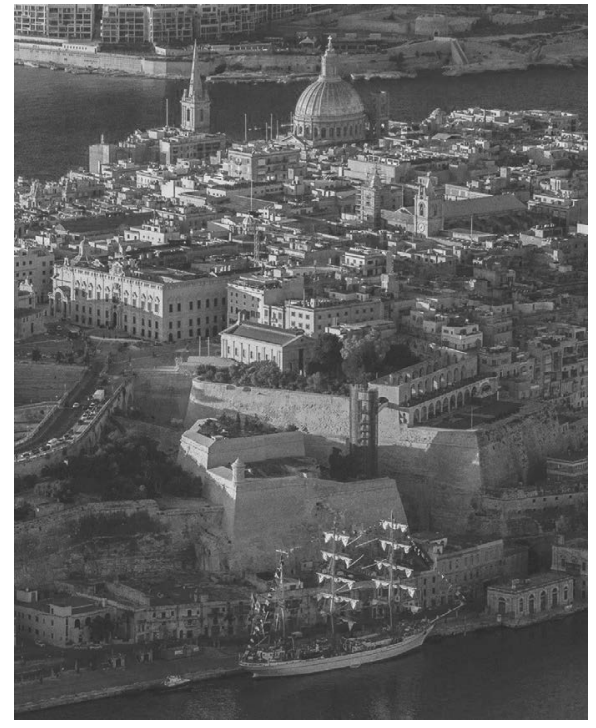

4. Креативний простір в Бастіоні святого Якова, Валлетта, Мальта

Відео «Пульс_Життя» / «УЗД» - це свого роду документ щодо «внутрішнього» життя дитини до народження, де переплелися медицинські свідоцтва і заклопотаність збереженням життя, в якому життя розглядається як об’єкт, зона ризику і сфера відповідальності. 1979 року американська художниця Мері Келлі у своєму творі «Post-Partum Document", що може бути перекладений як «Післяпологовий документ», описала події життя ї̈ сина після народження. У цій роботі мисткиня фізично відокремила природне від материнства, продемонструвавши її початкову вписаність в мову лабораторії [5, с. 1] та Лакана. Юлія Крістєва протидіяла специфічній напрузі феміністичної думки у Франції, що походять від надзвичайно впливової праці Сімони де Бовуар "Друга стать». Для Бовуар інтелектуальна жіноча емансипація і материнство знаходилися в повній опозиції одна до одної [6, с. 558]. Крістєва, навпаки, об’єднала ці дві концепції разом [7] і використала фігуру матері, аби утвердити поняття «дисидента", чи то чоловіка, чи то жінки, що є потужним аргументом проти тих, хто критикує її за зміцнення біологічного детермінізму. Цей «звільнений» погляд на матір розділила Елен Сіксу, яка в чудовій ліричній манері зазначила, що дитина не робить жінку менш революційною [8, с.?]. Як давно відмічали критики «біополітики» [9, с. 244], материнство як функція державних або квазідержавних інституцій і материнство як транс-індивідуація розмічають абсолютно різні політичні ситуації. «В тому чи іншому середовищі проект здатен “обростати” іншим контекстом, резонуючи із його конкретними проблемами: соціальною нерівністю в умовах декларованої демократії, впливом сусідства військових об’єктів на народжуваність і здоров'я дітей, кількість сиріт та безпритульних дітей в українських містах...» [10]. Відео «Народження» проблематизує право 

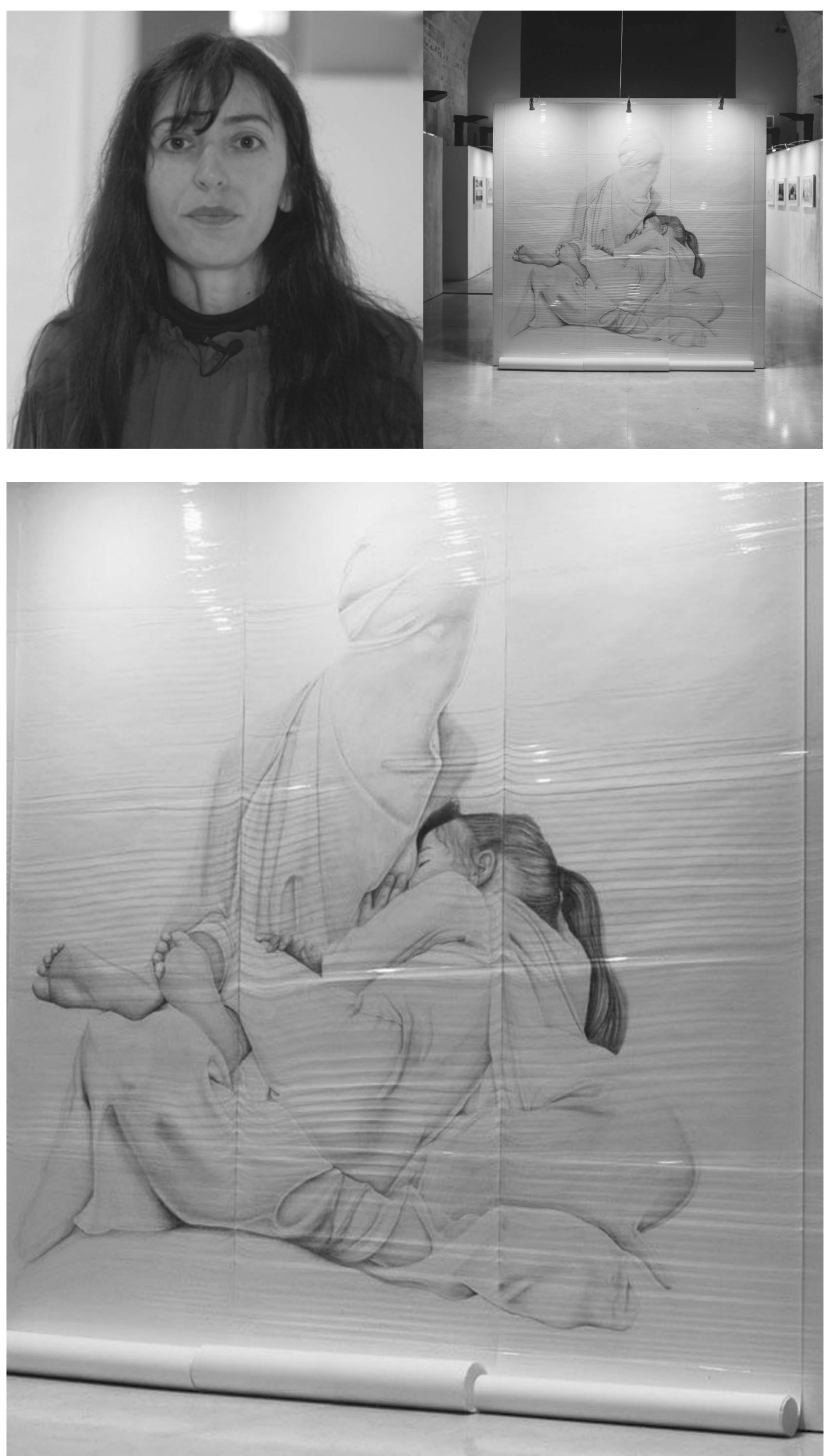

5, 6. Мір’яна Батініч «Рідке золото», «Арт + фемінізм 2020», Валлетта, Мальта 


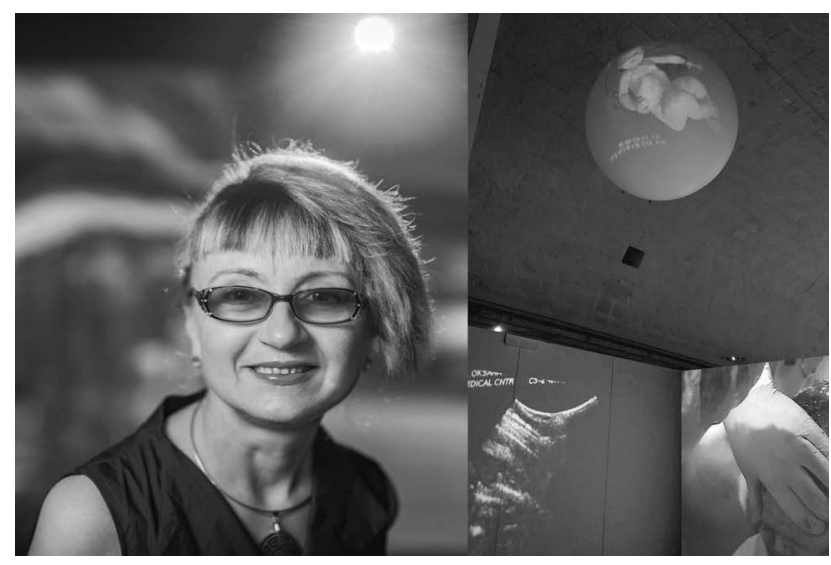

7, 8. Оксана Чепелик «Генезис», «Арт + фемінізм 2020», Валлетта, Мальта

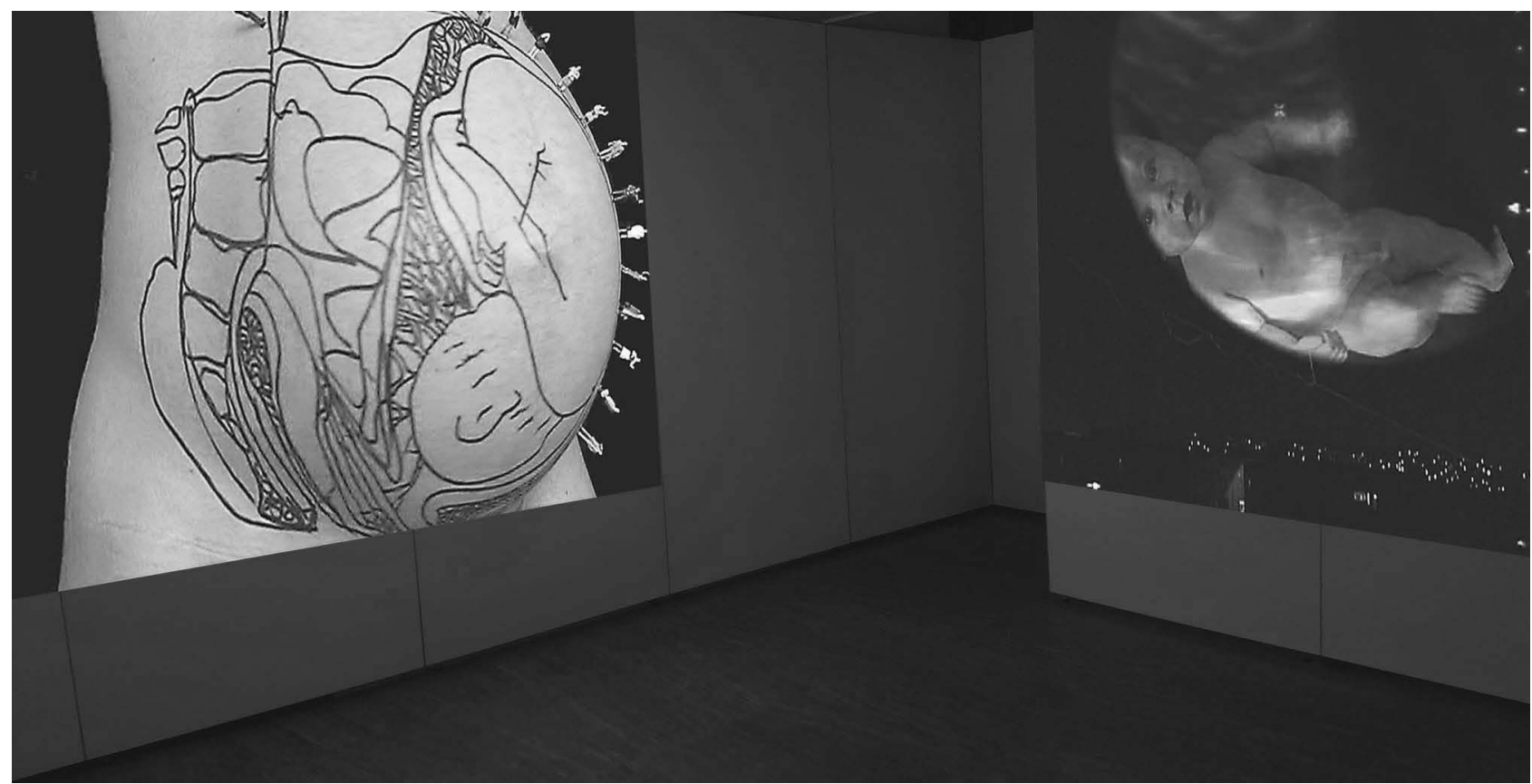

власності на плаценту. Отже, проект працює як агент, що розвиває зону опору з феміністичною перспективою. Кому належить плацента? Очевидно, не жінці, що оплачує свої пологи, або ж лікарю, а чи одразу безпосередньо корпорації, для якої плацента $є$ цінним матеріалом для виробництва шампунів та індустрії стовбурових клітин? На це моє запитання не змогла дати відповідь під час конференції «Біоетика та права жінок в ісламському контексті. Які проблеми?» [11], що відбулася в Iнституті перспективних досліджень IMéRA Екс-Марсельського університету (Марсель, Франція), навіть Ноуза Гюессу, професорка університету Касабланки (Марокко), наукова співробітниця з прав жінок та біоетики, президент Міжнародного комітету з біоетики ЮНЕСКО (2005-2007), членкиня експертного комітету ВОO3 та Комітету з питань етики i науки ALECSO. Сучасне мистецтво сьогодні змушене виконувати функції філософії, а митець, власне, працювати як іiї агент, розширюючи зони опозиції. Проект транслює тривогу i, за виразом Акілле Боніто Оліви, починає передавати «імпульси атрофованому м’язу глядацького сприйняття» [12, с. 33], апелюючи до його чутливості.

У контексті теми материнства варто зга- дати феміністичну відеороботу «44» Алевтини Кахідзе, створену для виставки «Свій простір» в ПінчукАртЦентрі 2018 року, про психологічний тиск і соціальні догмати, що функціонують у суспільстві у векторі «репродуктивного насильства» [13, с. 155], в якій мисткиня на питання «Чи є у вас діти?» в 44 роки відповідає «ні» 3 різним інтонаційно-сутнісним забарвленням, проживаючи цілий спектр емоцій, а у вислідку, відстоюючи право на власний вибір (іл. 9). А інша українська мисткиня, що працює з власним тілом і робить феміністські акції та перформенси в рамках руху «Квіти Демократії» (іл. 10), Марія Куликівська розкладає гіпсові вагіни в містах навколо будівель, що символізують владу і насильство.

До виставки «Арт + фемінізм 2020» включені роботи Деббі Каруна Дінглі, яка - не нове обличчя для мальтійської художньої сцени, хоча вона і вважає свою участь дещо незвичною для себе, адже, насправді, вона не любить щоденні жіночі турботи і так само не бере участі у «жіночих» проектах. 3 цієї короткої заяви мисткині зрозуміло, що слово «жіночий» породжує, швидше, негативні конотації або ж в кращому випадку виявляється порожнім означуваним - термін «жіноче мистецтво», не будучи роз'ясненим концептуально, визнача- 
9. Алевтина Кахідзе «44», «Свій простір», ПінчукАртЦентрі 2018
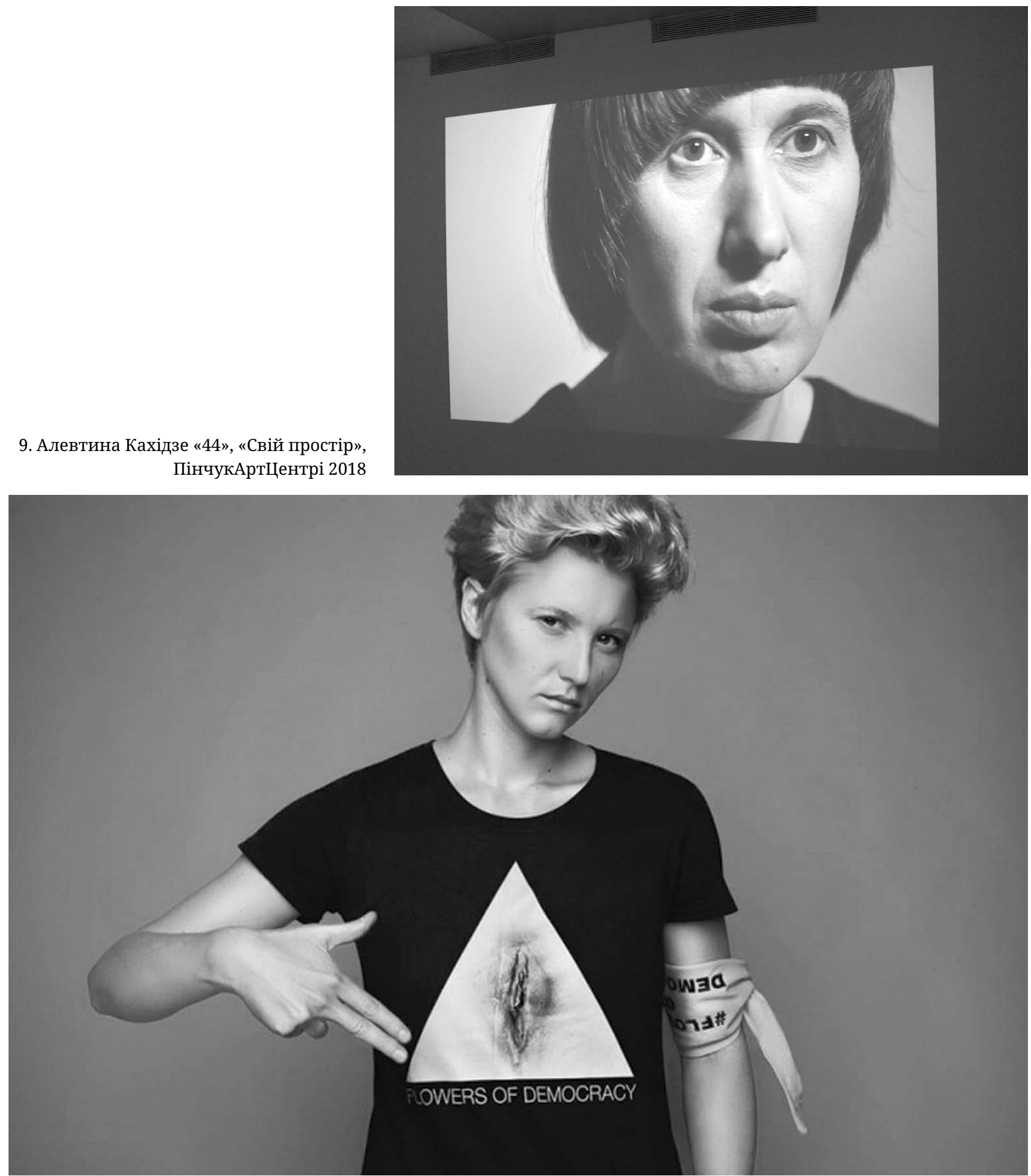

10. Марія Куликівська «Квіти Демократії»

ється через апеляцію до “справжнього» мистецтва, яке імплицитно мислиться як «чоловіче» [14, с. 163], причому, судячи 3 усього, ця думка поділяється і жінками-мисткинями.

Таке ставлення співвідноситься з еволюцією феміністичних світоглядних позицій і в Україні також. Більшість художниць в Україні, починаючи з 90-х років ХХ століття, також намагається уникнути гендерного прочитання своєї творчості як однобокого, вторинного та неповноцінного і вважає, що створений ними продукт з гендерної точки зору не- йтральний і процес їі подальшої валоризації не залежать від статі його творців, тим самим виключаючи навіть саму можливість вибудови широкого міжнародного дискурсу. Феміністичні ж практики демонструють порушення базового культурного стереотипу, де жінці притаманий один синонімічний ряд: природа, почуття, пасивність, безформенність, слабкість, а чоловікові - зовсім інший: культура, розум, активність, творчість, структура, сила. Адже мистецтво утворює соціальну сферу, воно вкорінене в соціальні струк- 


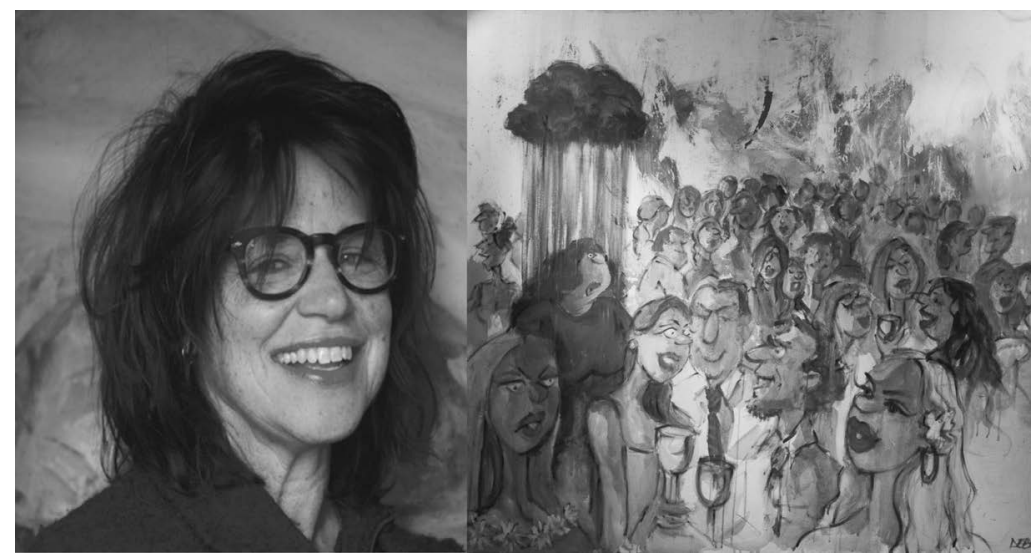

11. Деббі Каруна Дінглі «Вечірка у саду»,

«Арт + фемінізм 2020», Валлетта, Мальта

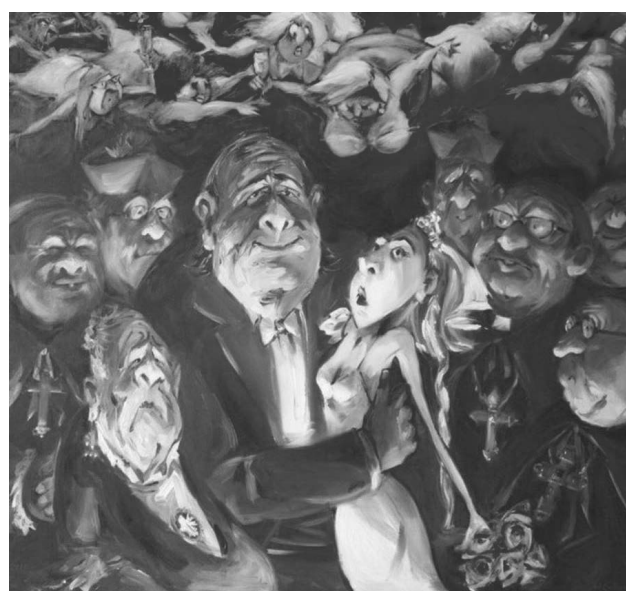

12. Деббі Каруна Дінглі «Товстий виродок» тури і оформлене діяльністю певних соціальних інститутів, «фалічних» за своїми принципами, таких як академія мистецтва, освітні установи, ринок, та міфом про божественного творця.

Елен Шоуолтер висловила думку, що жінка завжди говорить двома голосами, репрезентує дві точки зору - ту, яка нав'язана їй домінуючою в суспільстві ідеологією (тобто представляє «чоловічий» погляд на світ), і ту, яка пов'язана з думками і відчуттями соціальної групи, що репресується [15, с. 21]. Цей вислів ще раз підтверджує, що, знаходячись в опозиції чоловічому світу, жіноче мистецтво завжди прагне змінити стереотипи, що склалися, і культурні догми, тобто жіночий погляд володіє революційним потенціалом по відношенню до культурної традиції. На сьогодні на Заході політичний фемінізм 3 його радикальним іміджем давно поступився місцем більш рафінованому пост-фемінізму, основним об'єктом критики якого є філософія, мистецтво та інші соціальні дискурси, за допомогою яких суспільство артикулює своє відношення до проблеми статі. Ця зміна акцентів не означає зниження політичного пафосу, але форма його вираження стає явно іншою. Феміністичне мистецтво творить не тільки художній, але і соціальний акт, працюючи над становленням нових цінностей і нової свідомості.

У випадку з виставкою «Арт + фемінізм 2020», участь у ній для Деббі Каруни Дінглі склалася дуже влучно, адже вона працює над створенням колекції анімаційного живопису про матерів. У роботі відомої мальтійської художниці, яка називається «Вечірка у саду», відбувається виокремлення жіночої фігури, що зазнає соціального тиску, що часто відчувають жінки в суспільстві. Це робота з малярського циклу, в якому зображена фігура матері, що переживає важкі часи. На картині «Вечірка у саду» - мати, перебуваючи в дуже складній ситуації свого життя, останнє, що хотіла б робити, так це йти на вечірку. Але вона опиняється на вечірці разом зі своєю чорною хмарою, що переслідує її, і там-таки проливає на неї персональну зливу (іл. 11). Героїня думає про оточуючих, що вони розважаються і чудово проводять свій час, та в реальності інші люди також мають свої власні проблеми. Ці досить іронічні, навіть карикатурні зображення людської маси, що відображають авторський почерк мисткині, підтверджуть їі позицію, що характеризується невизначеністю вона одночасно виступає і адвокатом, і прокурором в цьому наративі, і стороннім спостерігачем, і залученим у цей вир персонажем. В їі роботі «Вечірка у саду» можна побачити її характерну методологію, що задіяна у грі, оскільки вона ілюструє численні перешкоди та упередження, що створює гендерний поділ, які долають жінки в суспільстві (іл. 12).

Тереза Дебоно - одна 3 учасниць виставки «Арт + фемінізм 2020», яка працює з фотографією. Десь три роки тому вона усвідомила, що була останньою особою, хто фіксує емоційний стан дівчини, яка покидає дім своїх батьків, аби одружитися. Фотографиня-документалістка Тереза Дебоно підходить до теми фемінізму використовуючи свій об’єктив. Проект Дебоно «Наречені на ліжках", що постав із ії роботи у весільній фотографії, досліджує життєві зміни та почуття наречених, у процесі переходу від дошлюбного до подружнього стану (іл. 13). Є багато запитань щодо цього, переважно таких як: чому дівчина має демонструвати символічний вихід з батьківського дому? Чому все ще наголошується на підготовці нареченої в батьківській спальній кімнаті, навіть якщо вона вже залишила рідний дім? У посланні, яке витікає з проекту, розглядається дихотомія традиції та сучасних очікувань. Мисткиня і надалі збирається досліджувати життя цих наречених, фотографуючи їх на ліжках і документуючи подальший шлях у їхнє нове життя.

Емма Фсадні демонструє цикл робіт з назвою «Промийте» (іл. 15), організований навколо зацікавленості авторки питанням, яким чином ми перебуваємо під вагомим впливом i обмежені багатьма специфічними гендерними упередженнями. Наймолодша учасниця виставки «Art + Feminism 2020» закликає дія- 
13, 14. Тереза Дебоно «Наречені на ліжках», «Арт + фемінізм 2020», Валлетта, Мальта
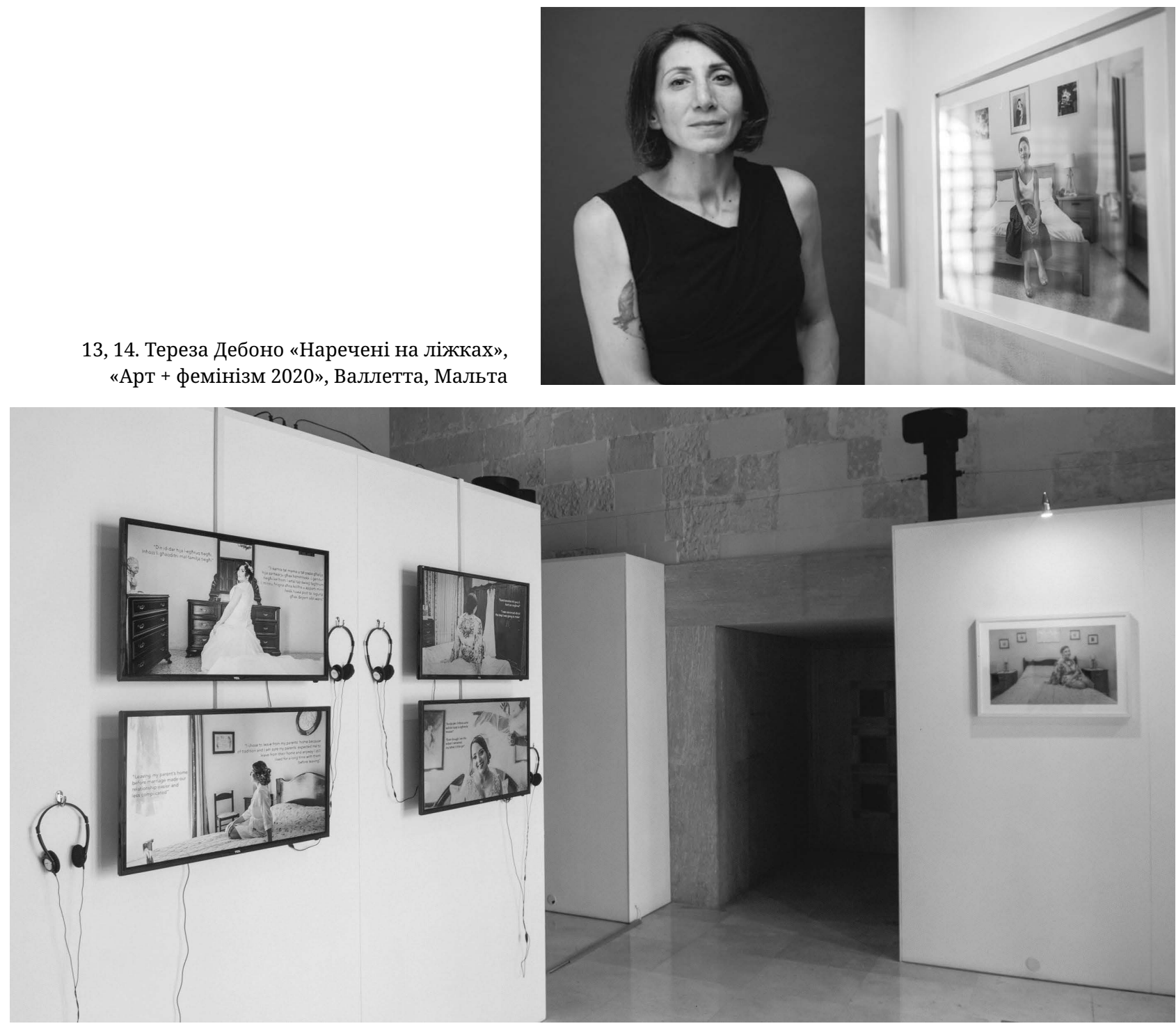

ти - змивати свідомі та підсвідомі обмеження, накладені соціальними, культурними та гендерними нормами. Фсадні втілює комплексність своїх концепцій засобами мінімалістичної естетики, візуально конденсуючи свої ідеї, не втрачаючи рівень складності. Вона надає перевагу двовимірним медіа, а саме ілюстрації, принтам та живопису, усвідомлюючи, що такий вибір дозволяє підтримувати необхідний рівень чутливості у творі. Мисткиня звернулася до популярної їдеї глобального промивання із протилежним результатом. Кожен день ми миємося, аби освіжитися кілька разів на день - цю ідею вмивання художниця застосовує до вимивання всього, що ми зібрали в сенсі впливів та ідей, запозичених в інших людей, всіх нашарувань, аби вимити їх. Ідея вимивання в цій роботі $є$ придатною для будь-якого гендера, тобто перебуває за межею гендера. Проект стосується забування привнесеної інформації, на користь переживання особистого досвіду і власного знання, аніж наслідування нав'язаних моделей і стереотипів, апропрійованих іззовні і взятих за основу. Він демонструє 160 ледь видимих малюнків одноформатних «промитих» облич (іл. 16).
Анна Гріма була запрошена до участі у виставці «Арт + фемінізм 2020», завдячуючи своїй яскравій творчій індивідуальності, адже вона має тривалі робочі стосунки з Арт Центром Креативний простір після персональної виставки, яка відбулася в Центрі творчості Сент-Джеймса Кавальє ще у 2002 році, а її робота «Шлях серця» перебуває в колекції Spazju Kreattiv. Анна Гріма на виставці представила живописний твір, назва якого «Звукова вібрація» (іл. 17). Ї̈̈ робота «П'ята і шоста чакра звукова вібрація" $€$ суміщеним диптихом, що досліджує взаємовідношення між свідомим і підсвідомим. Ця робота прагне проявити сучасні гендерні проблеми та прагнення балансу між розумом і тілом, баланс, який може бути проекцією на соціальну свідомість. Ії̈ живопис стосується метафізичної ідеї впливів - яким чином те, що ми кажемо і що ми думаємо, впливає на світ навколо нас. Анна представила диптих, розділений горизонтально на дві секції: верхня частина представляє сукупність свідомих знань і станів, а нижня частина представляе ідеї, які, можливо, у патріархальному суспільстві не сформульовані так добре. Авторка наголошує, що це - дуже важливий аспект у фемінізмі. 


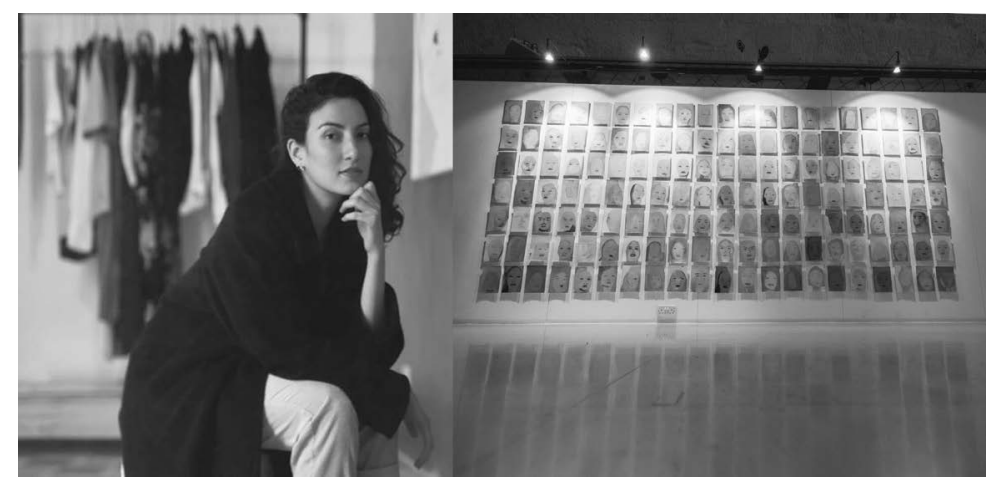

15, 16. Емма Фсадні «Промийте»,

«Арт + фемінізм 2020», Валлетта, Мальта
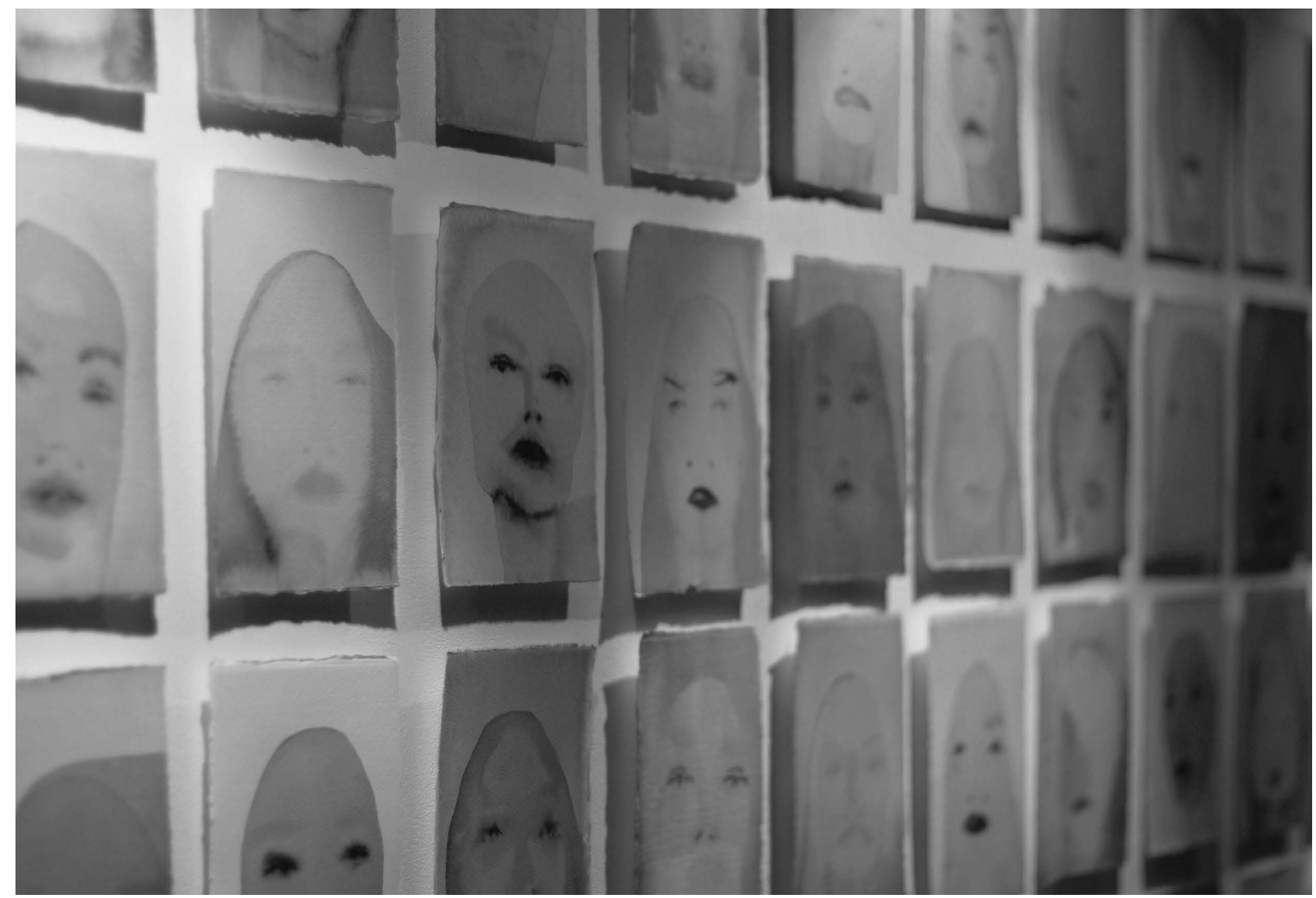

Вона творить ефект навколо жінки - подорож починається звідси. На полотні - оголена, майже прозора фігура жінки, що сидить на каменях над темними водами непроговорених історій, моря понять, почуттів, не сформульованих ідей (іл. 18).

Глорія Оярзавал - одна з обраних міжнародним журі учасниць виставки «Арт + фемінізм 2020» 3 Іспанії. Вона взяла участь у конкурсі задля участі у виставці, адже вона опрацьовує тему впливу колонізації на світогляд і сприйняття жінки в Африці, де мисткиня зазвичай працює (іл. 19). Ії проект ставить питання інфантилізації жінки, що була також експортована разом з колонізацією свідомості. Робота «Woman Go No'Gree» / «Жінка не погоджується» Глорії Оярзавал намагається розслідувати євроцентричні стандарти, які часто були нав'язані африканським країнам завдяки колоніалізму. Ця багатогранна робота ставить низку запитань щодо подолання стандартизації краси та знань, які часто розгляда- ються як визначені євроцентричною ментальністю. Назву запозичено з пісні «Леді» Фела Куті, нігерійського музиканта. Його пісня часто сприймалася як суперечлива через мізогіністичні (жононенависницькі) та феміністичні інтерпретації, які її оточують. У перекладі з креольської гавайско-англійської мови (відомої як «піджин») це означає, що «жінка не слухатиме» або "не погодиться", що вказує на багатогранність, явлену в рамках цієї роботи (іл. 20). До європейської колонізації жінка могла отримати владу в багатьох місцях Африки без гендерної диференціації. Доступ до влади був більше мотивований питаннями віку чи роду. Це відкриття наштовхує на думку, що універсалізація становища білої жінки по всьому світу є загрозою. Кожне суспільство, кожна група, кожен колектив має свої власні виклики і проблеми, а також власний шлях їх вирішення.

Свідченням того, що Глорія Оярзабал мислить політичними категоріями, є їі пряма 
17, 18. Анна Гріма «П’ята і шоста чакра звукова вібрація», «Арт + фемінізм 2020»,

Валлетта, Мальта
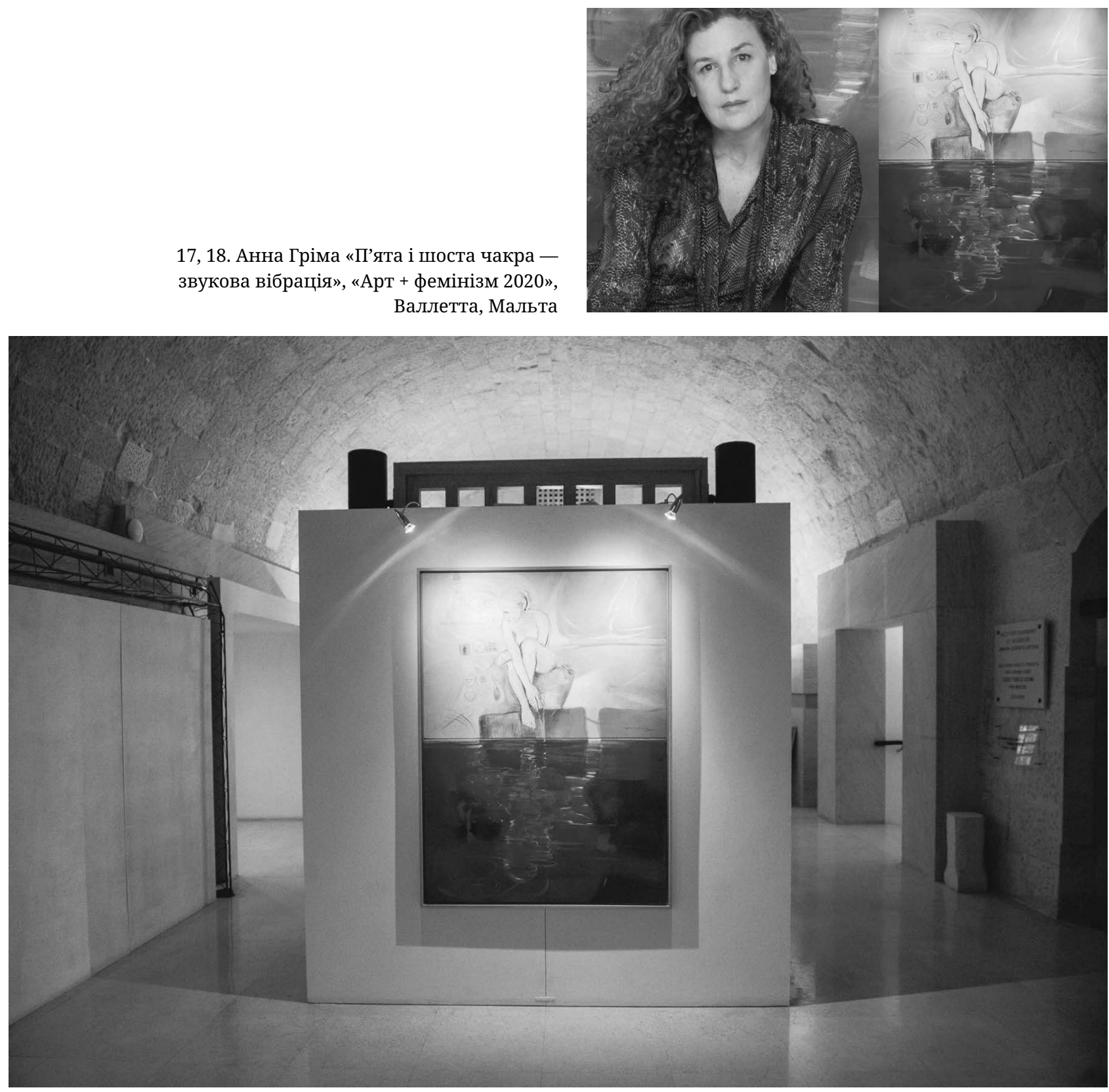

мова: «Давайте побажаємо нових способів міжгендерних стосунків, нових моделей міжкультурних діалогів, не на основі верховенства або виключної ієрархії, а, можливо, на основі ідентичностей, як індивідуальних, так і колективних, які зможуть природно розвиватися у суспільстві, де не треба було б бути невидимими задля просування» [2]. IIÏ проект, що складається 3 серії архівних зображень британського колоніального періоду, студійних зйомок у Лагосі в Нігерії, вуличної фотографії та витягів з африканської бібліотеки феміністичної літератури, розглядає вплив колоніалізму на концепцію жінки. Він візуалізує специфіку спотворення жінки в постколоніальному контексті на африканському континенті, з огляду на питання класу, раси, віку, статі та навіть здоров’я (іл. 21).

Робота Енріке Табоне складає ту частину виставки "Арт + фемінізм 2020", що є рефлексією на мистецькі твори, віднайдені в доісторичні часи. Проект Енріке Табоне, що назива- ється «Pre-Herstory» / "До-їісторія», досліджує фігурку матері, яку часто знаходять на доісторичних ділянках Мальтійських островів, і переосмислює її, надаючи їй розміри, які провокують припущення, що ця скульптура створена жінками. Проект представляє фігури, чи торси, як віднайдені в період матріархату, відсилаючи до відомих мальтійських мистецьких артефактів, таких як «Il-Mara-Hoxna» / «Товста жінка», «Il-Mara-Fertili» / «Жінка-родюча», «Венера» (аналог скіфських і половецьких баб у наших Причорноморських степах) та інші. Назви її скульптур «Наше тіло», поряд із її сестринською частиною «Моє тіло», i «Квітка» виступають як переконфігурація історії, де «ї̈» стає префіксом (іл. 22). Проект Енріке Табоне "До-їісторія" породжений реакцією мисткині на патріархальний погляд щодо так званої мальтійської богині-праматері, визначної до-(ії)історичної постаті. Використовуючи оргскло, характерне для творчості Енріке Табоне, мисткиня створює від- 

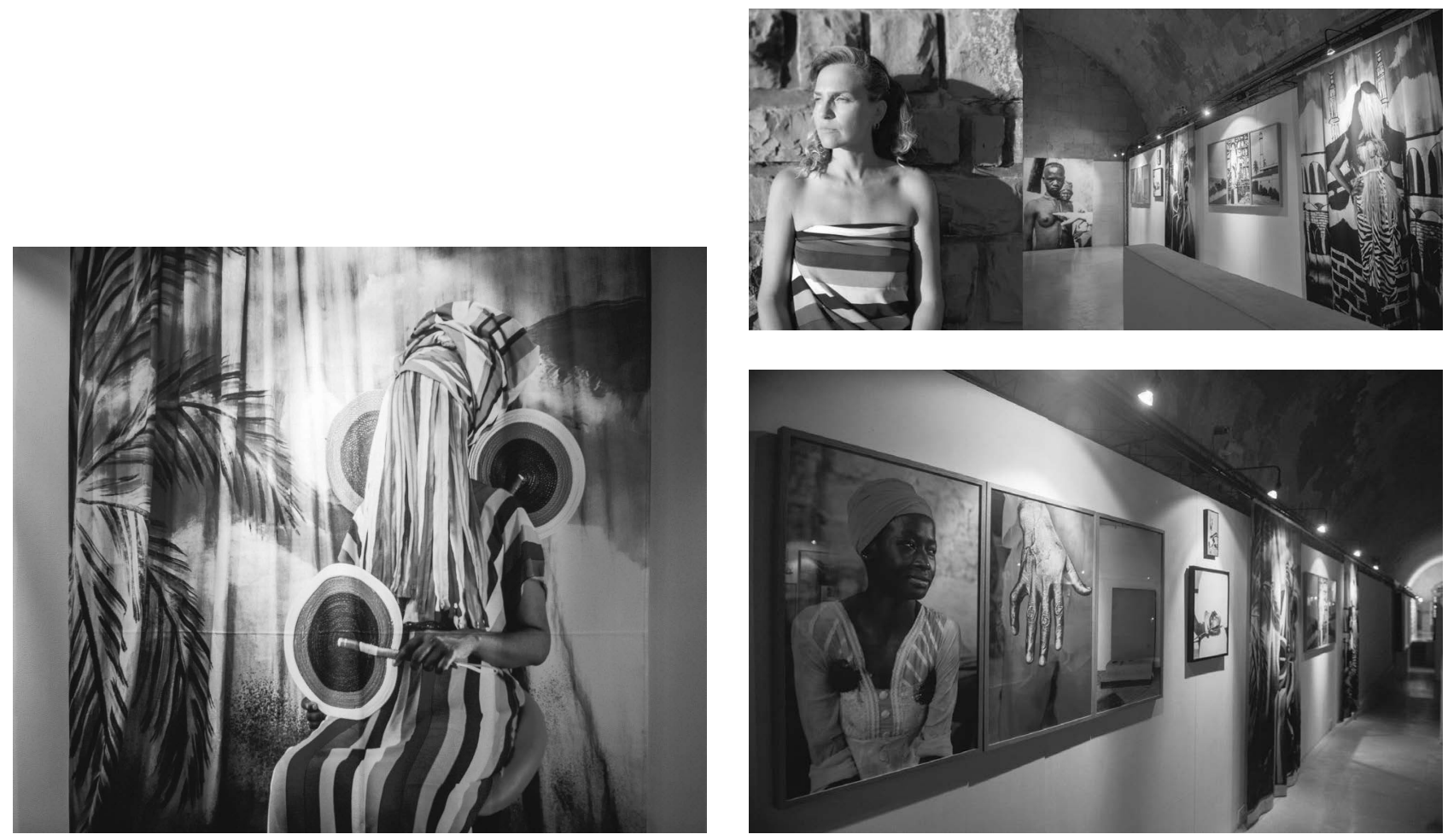

19, 20, 21. Глорія Оярзавал «Жінка не погоджується», «Арт + фемінізм 2020», Валлетта, Мальта

битки своїх форм в цих скульптурних творах і пов'язує їх з конотаціями до життя, відродження, регенерації та родючості, забезпечуючи ці доісторичні фігури сучасною рамкою. В цьому проекті мисткиня не просто наслідує архетипічні форми, а фокусується на жіночій перспективі, коли робота створена не Праксітелем, Фідієм чи Мироном, а жінкою для іншої жінки. А також якби ці скульптури були створені в наш час із застосуванням сучасного матеріалу і технологій. Художниця зумисне не бажає аж занадто деталізувати свою концепцію, так аби кожен міг отримати власний досвід від взаємодії з творами та сформувати свої власні ідеї щодо часового періоду та інтерпретацій свого емоційного і смислового сприйняття. Енріке Табоне створює частини відбитків форм жіночого тіла зі смуг прозорого пластику алгоритмічної побудови (іл. 23).

В рамках виставки «Арт + Фемінізм 2020» відбулася ретроспектива мальтійсько-американської мисткині Жани Бусуттіли Залеські (1920-2010), щоб відсвяткувати 100-річчя 3 дня народження та відзначити 10-ту річницю по ії смерті. Жана Залеські допомогла створити програму арт-резиденцій митців в Spazju Kreattiv у Валлетті, чим зробила не тільки мистецький, але й суспільний внесок у розвиток сучасного мистецтва Мальти. Як зазначив куратор Тоні Сант, це свято творчості Бусуттіли Залеські представляє твори 3 художньої колекції Fondazzjoni Kreattività (іл. 24), а також частину робіт з приватних колекцій по Мальті.

Родом 3 багатодітної родини, вона була найменшою з одинадцяти дітей, з Біркіркари Жана Бусуттіла Залеські емігрувала до Сполу- чених Штатів Америки зі своєю родиною у віці восьми років [16]. Залеські вивчала мистецтво у Філадельфійському коледжі мистецтв і дизайну Мура в США. Також вдосконалювала свої знання і навички в інституті Пратта, школі дизайну Парсонса та в рамках ліги студентів-митців у Нью-Йорку. Ї̈̈ роботи були представлені на виставках у США та на Мальті за її життя і після смерті. Натхненням для більшості робіт слугували їі відкриття Мальти під час численних відвідувань мальтійських доісторичних храмів, а також спогади про її дитинство (іл. 25). «Пристрасть вимагає вираження від митця / мисткині. Мої картини з'являються як результат цього запиту. (...) Я пишу роботи серіями. Я малюю сюжети, які викликають потребу висловити свої почуття з приводу конкретної теми. Часом, це може бути щось заховане глибоко в моїй підсвідомості, що проникає в сьогодення і запалює це завзяття. Тоді я повинна досліджувати цю тему, поки вогонь не перегорить, або інша тема не захопить мій дух, і саме тому моє мистецтво походить від дуже різних вражень», Жана Залеські [17, с. 47].

Серед важливих подій під час її кар'єри було запрошення 1975 року колишнього президента Джиммі Картера до Білого дому в складі делегації з п’яти жінок-художниць. Вона перебувала в арт-резиденції Центру творчих мистецтв у Вірджінії, отримуючи стипендію центру протягом 19752-001 років і допомагала встановити життєво важливий зв’язок між цією американською інституцією і Мальтійським університетом та Центром творчості Бастіоном святого Якова - СентДжеймс Кавалер. 1986 року в мерії Нью-Йорка 

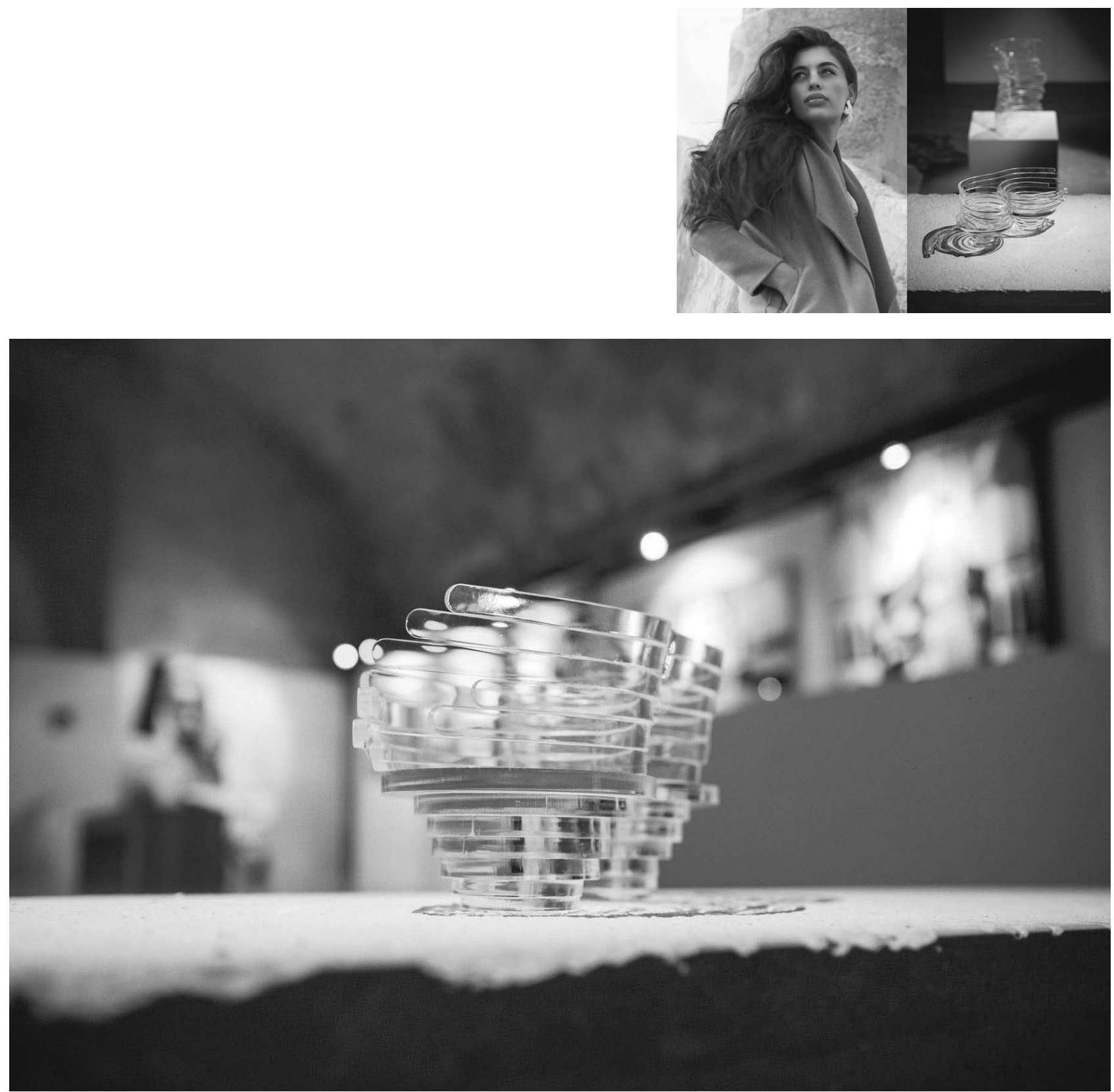

22, 23. Енріке Табоне «До-їісторія», «Арт + фемінізм 2020», Валлетта, Мальта

національна організація жінок вручила Жані Залескі премію Сьюзен Ентоні в галузі живопису [18, с. 644]. Окрім художніх виставок, її праці можна віднайти в низці книг, які можна поділити на дві категорії: ілюстрації та artist book / книги художників [19, с. 22]. Досить часто ці підходи поєднувалися.

14 лютого 2020 року відбувся прийом Мiністра національної спадщини, мистецтв та місцевого самоврядування доктора Хосе А. Еррера в рамках виставки «Мистецтво + фемінізм 2020» в Spazju Kreattiv, що засвідчив статусність міжнародного проекту для країни.

На жаль, із-за пандемії більшість запланованих мистецько-культурних подій на виставці були скасовані через коронавірус-19, але позитивною нотою прозвучало рішення про можливість долучитися до мистецтва через онлайн-експозицію, запропоновану організаторами, аби познайомити широку аудиторію з творами жінок-художниць, що сформували експозицію. Спочатку виставка планувалася до 7 квітня 2020 року, втім, 3 огляду на закриття центру для відвідування через пандемію, і зважаючи на важливість цього міжнародного проекту, наглядовою радою було прийняте рішення після відкриття експозиційних просторів для публіки 316 липня подовжити дію виставки до 23 серпня 2020 року.

Якщо звернутися до офіційної хронології українських проектів і виставок, що усталено пов'язуються 3 феміністичними чи гендерними пошуками: «Пошук примхливих зваб» в Галереї «Децима», Львів (1993); «Рот Медузи» в ЦСМ «Брама», Київ (1995); «Ніжність» в ЦСМ при НАУКМА, Київ (2003); «Гендер в Ізоляції: 


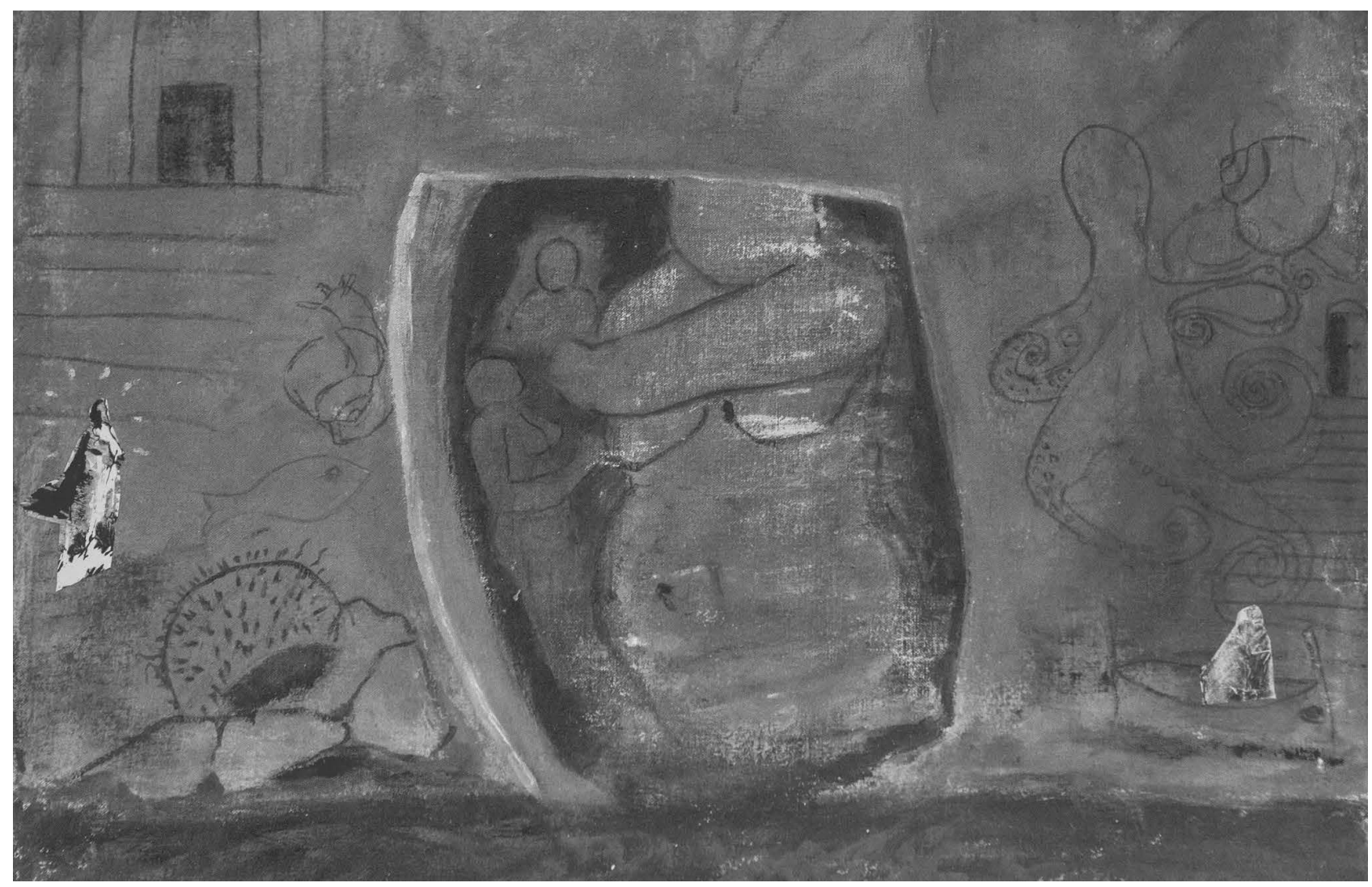

24. Жана Бусуттіл Залеські «Без назви (з Мальти: Спогади та дослідження 1989-2001 років)», «Арт + фемінізм 2020», Валлетта, Мальта

право на самоконструювання в умовах патріархату» в Фонді Ізоляція, Донецьк (2012); «Що в мене є від жінки?» та «Материнство» в ЦВК, Київ (2015); «Теxtus, вишивка, текстиль, фемінізм» в ЦВК, Київ (2017); “Свій простір» в ПінчукАртЦентрі в Києві (2018-2019) [20, с. 214-217]. В цьому переліку відсутній як авторський проект «Генезис» в Домі Художника, Київ (2008), так і «Генезис-2» в Музеї сучасного мистецтва України, Київ (2011), тож залучення його нового етапу до українського дискурсу через міжнародну репрезентацію у виставці «Арт + Фемінізм 2020" є аж надто актуальним.

В рамках виставки відбулися заходи едітону - низка семінарів з редагування та правок Вікімедії, аби зменшити гендерний розрив у Вікіпедії задля висвітлення роботи жінок-художниць та їх внеску у мистецтво. Феміністичні едітони відбуваються в багатьох важливих музеях по цілому світу, серед яких МОМА в Лондоні, Новий Музей в Нью-Иорку, Наммер Музей в Лос-Анджелесі та інші. Мета цих семінарів Art-Feminism edit-a-thon (лінгвістичне поєднання слів edit - редагування та marathon - марафон) - створити та редагувати сторінки Вікіпедії про жінок-художниць на Мальті, особливо тих, хто бере участь у пов'язаних з фемінізмом і гендерною проблематикою виставках, тобто свідомо орієнтованих на відновлення рівноваги у суспільстві та мистецтві. Термін «хакатон» вже увійшов у повсякдення і в наш лексикон, як захід, під час якого різні «спеціалісти в галузі роз- робки програмного забезпечення інтенсивно і згуртовано разом працюють над розв'язанням якоїсь проблеми» [21, с. ?], або задля освітніх чи соціальних цілей, тож едітатон на часі. Завдяки цим семінарам у Вікіпедії з'явилися розділи, присвячені творчості мальтійських художниць, учасниць виставки, і навіть міжнародні учасниці отримали сторінки на спеціальному ресурсі Вікімедії. Варто зазначити, що в українському сегменті Вікіпедії Жана Бусуттіл Залеські представлена краще, ніж більшість українських мисткинь, що свідчить про відсутність культурної політики щодо зменшення гендерного розриву і державної стратегії з фокусом на висвітленні доробку жінок-художниць, їх внеску у мистецтво та відновлення рівноваги у суспільстві та мистецтві в Україні, аналогічної мальтійській.

Жінки, загалом, не зобов'язані робити проекти саме про жінок і тим більше не зобов’язані бути феміністками, але феміністки виступають завжди помітніше і яскравіше. Жан-Крістоф Амман виявляє статус жінки приблизно так: «Сучасна свідомість прямує до подолання логоцентризму, а тому майбутнє мистецтва належить жінці. Жіноча сила є “цілющою”, тому є доречним звернення до трансфузій (можемо прочитати медичне пояснення цього терміну, в контексті сучасного мистецтва: трансфузія є процесом передачі крові кровоносній системі організму), аби лікувати культурну “анемію”, бо це - сила маргінального поля, сила периферії [22]. 


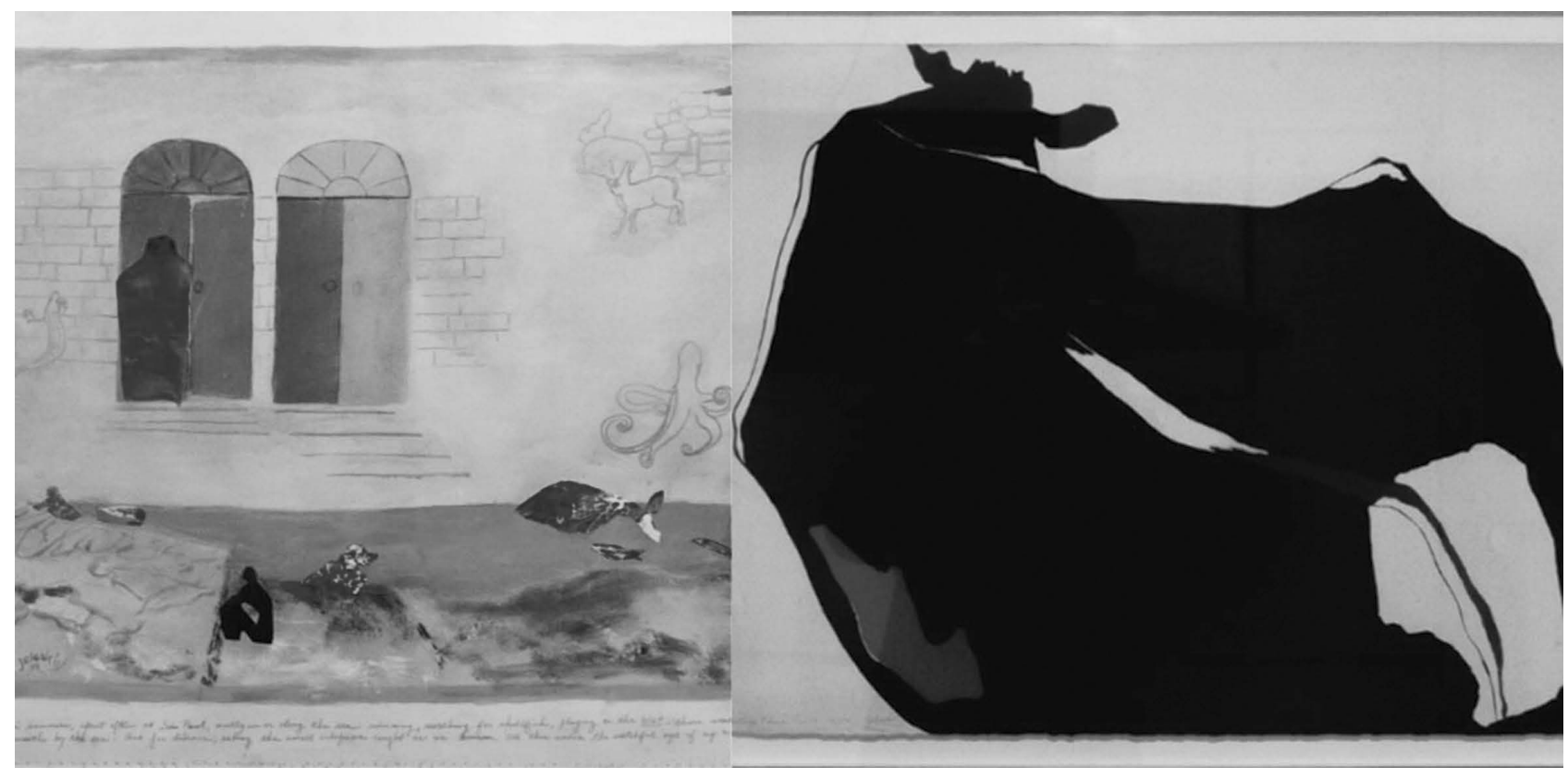

25. Жана Бусуттіл Залеські «Арт + фемінізм 2020», Валлетта, Мальта

Висновки і перспективи подальших розвідок у даному напряму. Наведені проекти, продемонстровані в рамках «Арт + фемінізм 2020» в Spazju Kreattiv на Мальті у неконвенційний спосіб торкаються проблем, актуальних для сьогонішнього світу. Увага до власного доробку сучасного мистецтва з фокусом на фемінізмі може слугувати прикладом для культурної політики України.

Для української мистецької спільноти нагальною є небхідність:

- набуття Україною власної суб’єктності в мистецтві та ії залучення до знаних міжнародних подій;

- залучення проектів, продемонстрованих за кордоном до українського мистецького дискурсу, що може стати приводом для дискусій, актуальних для українських реалій;

- культурологічні рефлексії гендерної проблематики і вбудовування українського сучасного мистецтва в глобальні явища;

- зменшення гендерного розриву у Вікіпедії задля висвітлення роботи українських художниць та їх внеску у мистецтво.

Будучи щорічною виставкою «Арт + Фемінізм", цей проект має у перспективі всі шанси бути об'єктом подальших розвідок, так само як і дослідження фемінізму в Україні, і робота на ниві гендеру теж ще далека до свого завершення.

\section{Література}

1. Глеба Г. Оксана Чепелик: «Я розпочала гендерну тему задовго до...». Коридор журнал про сучасну культуру. 11 грудня 2018. URL: http://www.korydor.in.ua/ua/woman-in-culture/oksana-chepelikfeminizm-gender.html (дата звернення: 15.07.2020).

2. Vassallo S. Art + Feminism In the Capital: Female Artists At Spazju Kreattiv Have A Strong Message To Share. March 3, 2020. URL: https://lovinmalta.com/lifestyle/art/spazju-kreattiv-art-feminism/ (Last accessed: 15.07.2020).

3. Wolfsberg TG, McEntyre J, Schuler GD. Guide to the draft human genome. Nature. 409 (6822): (February 2001). P. 824-826.

4. Дронова. Ю. А. Что нужно знать о суррогатнном материнстве. М.: Городец, 2007. 112 с.

5. Kelly M. Post-Partum Document, Social Science Routledge\&Kegan Paul, London, 1985. 212 p.

6. Бовуар С. Второй пол. Т. 1, 2: Пер. с франц. / Общ. ред. и вступ. ст. С.Г. Айвазовой, коммент. М. В. Аристовой. М.: Прогресс; СПб.: Алетейя, 1997. 832 с.

7. Kristeva J. Motherhood today, Colloque Gypsy V. Rêves de femmes. Vendredi 21 et samedi 22 octobre 2005-10-28. URL: http://www.kristeva.fr/motherhood.html (Last accessed: 15.07.2020).

8. Фуко М. Воля к истине: по ту сторону знания, власти и сексуальности. Работы разных лет. Пер. с франц. М., Касталь, 1996. 448 с.

9. Сиксу Э. Хохот Медузы / пер. с англ. А. Липовской // Введение в гендерные исследования. Хрестоматия. Харьков: ХЦГИ, 2001. Ч. 2. С. 799- 821.

10. Скляренко Г. Життя на замовлення: про проект Оксани Чепелик. Сучасне мистецтво: Зб. Наук. праць. Випуск V. К.: ІПСМ АМУ, Х.: Акта, 2008. С. 106-109.

11. Guessous N. (2019) Femmes en contextes musulmans contemporains: Impacts des progrès biotechnologiques sur les pratiques, les normes et les valeurs en vigueur. URL: https://imera.univamu.fr/fr/node/3701 (Last accessed: 15.07.2020). 
12. Акилле Бонито Олива. Искусство между идентичностью и гомогенностью / перевод Валерия Серовского // Художественный журнал. М.: ХЖ, № 56. 28.05.2004. Стр. 32-35.

13. Шиллер В. Алевтина Кахідзе «Тільки для чоловіків, або суджений-ряджений, з'явись мені у дзеркалі» // Чому в українському мистецтві є великі художниці (упорядниця Катерина Яковленко). К.: Publish Pro, 2019. 224 с.

14. Бредихина Л. Ребро Евы, плечо Адама и другое. Гендерные исследования, № 16 (2/2007). Харьков: Харьковский центр гендерных исследований, 2007. 234 с.

15. Showalter E. New feminist criticism: essays on women, literature, and theory. New York: Pantheon Books, 1985. 403 p.

16. Fiorentino E. Malta musings and mnemonics // The Sunday Times of Malta. 9 June 2002.

17. Zaleski J. (2002). Memories and Explorations. Malta: St James Cavalier Centre for Creativity. P. 47.

18. Sleeman E. The International Who's Who of Women 2002. Psychology Press, 2001. 680 p.

19. Zaleski J. Cow/lines. Honig, Edwin. Providence, R.I.: Copper Beach Press, 1982.

20. Яковленко К. Чому в українському мистецтві є великі художниці. К.: Publish Pro, 2019. 224 с.

21. Leckart S. The Hackathon Is On: Pitching and Programming the Next Killer App // Wired. March 2012.

22. Амман Жан-К. Логоцентризм и русское искусство (интервью брала Галина Мейн) // Художественный журнал. № 9. М: ХЖ, 1996. URL: http://moscowartmagazine.com/issue/97/article/2167 (дата звернення: 02.07.2020).

\section{References}

1. Gleba G. Oksana Chepely `k: «Ya rozpochala gendernu temu zadovgo do...». Kory`dor zhurnal pro suchasnu kul `turu. 11 grudnya 2018. URL: http://www.korydor.in.ua/ua/woman-in-culture/oksana-chepelik-feminizm-gender.html (data zvernennya: 15.07.2020).

2. Vassallo S. Art + Feminism In the Capital: Female Artists At Spazju Kreattiv Have A Strong Message To Share. March 3, 2020. URL: https://lovinmalta.com/lifestyle/art/spazju-kreattiv-art-feminism/ (Last accessed: 15.07.2020).

3. Wolfsberg TG, McEntyre J, Schuler GD. Guide to the draft human genome. Nature. 409 (6822): (February 2001). R. 824-826.

4. Dronova. Yu. A. Chto nuzhno znat`o surrogatnnom matery`nstve. M.: Gorodecz, 2007. $112 \mathrm{~s}$.

5. Kelly M. Post-Partum Document, Social Science Routledge\&Kegan Paul, London, 1985. 212 r.

6. Bovuar S. Vtoroj pol. T. 1, 2: Per. s francz. / Obshh. red. y` vstup. st. S.G. Ajvazovoj, komment. M.V. Ary`stovoj. M.: Progress; SPb.: Aletejya, 1997. 832 s.

7. Kristeva J. Motherhood today, Colloque Gypsy V. Rêves de femmes. Vendredi 21 et samedi 22 octobre 2005-10-28. URL: http://www.kristeva.fr/motherhood.html (Last accessed: 15.07.2020).

8. Fuko M. Volya k y`sty`ne: po tu storonu znany`ya, vlasty`y` seksual `nosty`. Rabotы raznыx let. Per. s francz. M., Kastal`, 1996. 448 s.

9. Sy`ksu Э. Xoxot Meduzi / per. s angl. A. Ly`povskoj // Vvedeny`e v gendernыe y`ssledovany`ya. Xrestomaty`ya. Xar`kov: XCzGY`, 2001. Ch. 2. S. 799-821.

10. Sklyarenko G. Zhy ttya na zamovlennya: pro proekt Oksany`Chepely`k. Suchasne my`stecztvo: Zb. Nauk. pracz`. Vy`pusk V. K.: IPSM AMU, X.: Akta, 2008. S. 106-109.

11. Guessous N. (2019) Femmes en contextes musulmans contemporains: Impacts des progrès biotechnologiques sur les pratiques, les normes et les valeurs en vigueur. URL: https://imera.univamu.fr/fr/node/3701 (Last accessed: 15.07.2020).

12. Aky `lle Bony`to Oly`va. Y`skusstvo mezhdu y`denty`chnost `yu y`gomogennost `yu / perevod Valery`ya Serovskogo // Xudozhestvennыj zhurnal. M.: XZh, \# 56. 28.05.2004. Ctr. 32-35.

13. Shy 'ller V. Alevty`na Kaxidze «Til `ky`dlya cholovikiv, abo sudzheny`j-ryadzheny`j, z'yavy`s `meni u dzerkali» // Chomu v ukrayins `komu my`stecztvi ye vely`ki xudozhny`ci (uporyadny`cya Katery`na Yakovlenko). K.: Publish Pro, 2019. 224 c.

14. Bredy`xy`na L. Rebro Evы, plecho Adama y`drugoe. Gendernыe y`ssledovany`ya, \# 16 (2/2007). Xar`kov: Xar`kovsky`j centr gendernыx y`ssledovany`j, 2007. 234 s.

15. Showalter E. New feminist criticism: essays on women, literature, and theory. New York: Pantheon Books, 1985. 403 p.

16. Fiorentino E. Malta musings and mnemonics // The Sunday Times of Malta. 9 June 2002.

17. Zaleski J. (2002). Memories and Explorations. Malta: St James Cavalier Centre for Creativity. R. 47.

18. Sleeman E. The International Who's Who of Women 2002. Psychology Press, 2001. 680 p.

19. Zaleski J. Cow/lines. Honig, Edwin. Providence, R.I.: Copper Beach Press, 1982.

20. Yakovlenko K. Chomu v ukrayins`komu my`stecztvi ye vely`ki xudozhny`ci. K.: Publish Pro, 2019. 224 c.

21. Leckart S. The Hackathon Is On: Pitching and Programming the Next Killer App // Wired. March 2012. 22. Amman Zhan-K. Logocentry`zm y` russkoe y`skusstvo (y`nterv `yu brala Galy`na Mejn) // Xudozhestvennij zhurnal. \# 9. M: XZh, 1996. URL: http://moscowartmagazine.com/issue/97/article/2167 (data zvernennya: 02.07.2020). 


\section{Chepelyk 0.}

\section{Art + Feminism 2020: Ukrainian and Worldwide Contexts}

The artistic achievements of international artists such as Mirjana Batinić, Oksana Chepelyk, Therese Debono, Debbie Caruana Dingli, Emma Fsadni, Anna Grima, Gloria Oyarzabal and Enriqué Tabone, Jean Busuttil Zaleski, were examined at the exhibition «Art + Feminism 2020» held from February 7 to August 23, 2020 at the St James Cavalier Centre for Creativity in Malta, dedicated to feminist issues, with the aim to include them into national cultural study discourse, as a subject for reflections and discussions.

Topics developed by artists, such as empowerment of young girls and women to combine professional realization and motherhood, bioethics and women's rights in the commercialization of reproductive technologies, the conflict between traditional gender norms and prejudices and modern expectations, untold stories in patriarchal society, historical infantilization of women through the colonization of consciousness, art history in the era of matriarchy with a focus on women's perspective through a vision of prehistoric artifacts with a contemporary frame and the use of new technologies. A wide range of artistic practice, from traditional painting, graphics and sculpture, to those related to the use of media: photography, video and data-driven media installation, is pointed.

The importance of cultural study and reflections on gender issues and the integration of Ukrainian contemporary art into global phenomena for the development of theory and practice, but also the importance of involving Ukrainian projects demonstrated abroad in the Ukrainian art discourse are emphasized. The fruitfulness of efforts to reduce the gender gap in Wikipedia in order to highlight the work of women artists and their contribution to art was noted.

The place of contemporary feminist art is defined as a cultural and political phenomenon in social life, which works for the formation of new values and new consciousness and can serve as a tool for cultural policy of Ukraine.

Keywords: art, feminism, gender, equality, reproductive technology, colonization of consciousness.

\section{Чепелик О. В.}

\section{Арт + феминизм 2020: украинский и мировой контексты}

Рассмотрено художественное наследие международных художниц, таких как Мирьяна Батинич, Оксана Чепелик, Дебби Каруана Дингли, Тереза Дебоно, Эмма Фсадни, Анна Грима, Глория Оярзабал, Энрике Табоне, Жана Бусуттил Залески, представленное на выставке «Арт + феминизм 2020», проходившей 7 февраля - 23 августа 2020 года в Арт Центре Креативное пространство на Мальте, посвященное феминистической проблематике, для привлечения его к национальному культурологическому дискурсу как повод для размышлений и дискуссий.

Рассмотрены темы, с которыми работают художницы, такие как расширение прав и возможностей молодых девушек и женщин для совмещения профессиональной реализации и материнства, биоэтика и права женщин в условиях коммерциализации репродуктивных технологий, конфликт между традиционными гендерными нормами, предрассудками и современными ожиданиями, непроговоренные истории в патриархальном обществе, историческая инфантилизация женщины посредством колонизации сознания, история искусств в епоху матриархата с фокусом на женской перспективе и обеспечением видения доисторических артефактов современной рамкой и использованием новых технологий. Отмечен широкий спектр художественных практик, которыми занимаются художницы - от традиционной живописи, графики и скульптуры до таких, что связаны с использованием медиа: фотографий, видео и управляемых данными медиа-инсталляций.

Подчеркнута важность культурологических рефлексий гендерной проблематики и встраивания украинского современного искусства в глобальные явления для развития теории и практики, а также важность привлечения украинских проектов, продемонстрированных за рубежом, к украинскому художественному дискурсу. Отмечена плодотворность усилий по уменьшению гендерного разрыва в Википедии для освещения работы женщин-художниц и их вклада в искусство.

Определено место современного феминистского художественного наследия - как культурного и политического явления в общественной жизни, которое способствует становлению новых ценностей и нового сознания и может служить инструментом культурной политики Украины. Ключевые слова: искусство, феминизм, гендер, равенство, репродуктивная технология, колонизация сознания. 